\title{
O ARCĂ NOETICĂ ŞI EUHARISTICĂ A LOGOSULUI PENTRU POSTMODERNITATE: BISERICA „SFINȚILOR IOAN BOTEZĂTORUL, TEOLOGUL ŞI HRISOSTOMUL" ŞI A „SFINȚILOR MARTIRI BRÂACOVENI" DE LA ALBA IULIA
}

Jan Nicolae*

\begin{abstract}
The church "Saint John (the Baptist, the Theologian and Chrysostom) and Saint Brancovan Martyrs" from Alba Iulia has a special story, unfolded for a whole decade, 2005-2015, being debated from architectural and iconological point of view in the cultural and ecclesiastic Romanian area, after 1989. Its architecture, drafted by the most important contemporaneous Romanian architect, Dorin Ştefan, was theorized by Augustin Ioan as privileged example of „retrofuturism" concept and falling into archetypal and minimalist trend. The form proposed by the architect wishes to be a resonance box of liturgical mystery, an ecumenical shrine, an arch of converting (arca noetica), a diachronic metaphor of basilican morphologies etc. Realized symbolic synthesis has multiple sources: Brancusian plastic morphologies, Arbore church, an Athonite cell-church, chapel of Corbusier from Ronchamp, a series of minimalist installations. Preparation for embellishment with fresco generated two iconographic projects (Sorin Dumitrescu and Ioan Popa), one diagrammatic and another typological, being chosen the last one, based on a theology of signs connected with baptismal and Eucharistic typology (Baptism and Eucharist, Church Easter). Iconographic programme made by painter Ioan Popa in collaboration with parish priest Jan Nicolae includes an unwound rotulus with images and texts, between mega-scenes depicted between the two minor apses: Anastasis and Pentecost, connected in a rhombus placed over a square with the scene of germination of primordial waters, in the first case, and with that of Throne of Ethimasia, in the second, thus being created,
\end{abstract}

* PhD Assistant Professor, "1 Decembrie 1918" University of Alba Iulia, (Faculty of Orthodox Theology), Romania. 
theologically, a connection between protology/ historicity and eschatology, and morphologically, the image of a baptismal font and universal panel. The two images include the hermeneutical extremities of the ensemble, the two polarities, water and fire, reuniting in the monumental image of Our Lady of the Sign and Orant from the apse of the altar, baptistery-chalice of the Church. Out of the four iconographic registers, two are dedicated to typological lecture of liturgical Bible (prefigurations, sacrifices, symbols), the median one to life of our Saviour, the lower one to hagiographic cycle, communion of saints, in anthropologic and cultural arrangement under the sign of diversity of vocations and charisms. The church from Alba Iulia represents a theological and esthetic manifest, its exquisite architectural and iconological programme being under the sign of finding Eucharistic and spiritual ethos specific to primary Christianity, local connexions with Eucharistic and philokalic renewal.

Keywords: arca noetica, rotulus of kingdom, postmodernity, arhitectural concept, iconographic programme, Dorin Ştefan, Ioan Popa, Virgil Scripcariu

\section{Introducere: retrofuturismul sau schimbarea la față a arhitecturii ecleziale în postmodernitate}

Atunci când au dorit să ilustreze dinamica Bisericii în istorie pentru afişul simpozionului teologic internaţional „Ethosul misionar al Bisericii în postmodernitate”, o parte din colegii mei s-au gândit la fresca din bolnița mânăstirii Hurezi, Corabia Bisericii, imagine admirabil analizată de vlădica Bartolomeu Anania în „Cerurile Oltului", şi pe care am numit-o icoană a Logosului euharistic. Mitropolitul cărturar constata că cei care se împotrivesc Bisericii nu țintesc în primul rând spre persoana istorică a Mântuitorului, ci spre Hristos euharistic. În cele din urmă, s-a decis reprezentarea acestui ethos printr-o imagine nouă, alegându-se chipul unei biserici din Alba Iulia, o arcă-chivot noetică şi euharistic(ă), pregătită pentru sfințire în 17 mai a.c, în duminica dinaintea sărbătorii Înălțării Domnului.

Fiecare biserică, „entitate straniu-familiară, împlântată în miezul comunității” (Augustin Ioan), are o ,poveste” a facerii sale şi un ,contract iconografic”, un pattern generativ, o viziune-cadru, matcă a întruchipării sale de la concept la corpul zidit şi împodobit. 
Una din cugetările cele mai cuprinzătoare dedicate modului în care se mai pot face biserici astăzi stă sub semnul conceptului paradoxal de retro-futurism, care ilustrează minunat modul tainic de întrupare culturală a Logos-ului în biserica de la Alba Iulia în chipul unei noutăţi vechi:

„Paradoxul - îmbucurător - arhitecturii creștine este acela că, expresie a unei religii teleologice, ea trebuie să fie în acelaşi timp arhaică şi viitoare. Recapitularea inspirată a tradiţiei bimilenare este unul dintre scopurile ei; dar, în acelaşi timp, aşteptarea celei de-a doua veniri face din biserică un loc orientat nu doar în sensul propriu, cardinal, al termenului, ci și în sensul său temporal. Termenul de retrofuturism descrie atunci acel mod de a face arhitectură în care investigarea tradiției descoperă în aceasta lucruri suficient de îndepărtate în timp şi de surprinzătoare încât insolitarea să se producă nu în sensul ,inventării”, ci al redescoperirii. Această arhitectură trebuie să fie în acelaşi timp o perpetuă recapitulare şi o neostenită investigare. Plasarea în contexte contemporane şi rescrierea acestor elemente localizate în propria tradiție face din reiterare o bună școală de compoziție, iar din arhitectura rezultată - una ,veche, nouă". În acelaşi timp, experimentul îşi are locul său în exact acelaşi teritoriu, al arhitecturii creștine. Aceasta pentru că investiga-rea celei mai bune adecvări a logos-ului în materia înzidită nu trebuie să înceteze a ne preocupa, în așteptarea judecății celei înfricoșate. Insolitarea este un mijloc de a atrage atenția asupra lucrării logos-ului în lume. Dacă ne uităm cu atenție - şi pe repede-înainte - la modul în care s-a schimbat la faţă arhitectura creştină în cele optsprezece secole de prezenţă triumfală, vom avea dinaintea ochilor paradigma experimentului însuşi. Este aici o perpetuă activitate de adecvare la spaţii existente şi a spațiilor existente la tiparele în evoluţie ale necesităţilor liturgice; o modelare neîncetată de tipuri strămutate dintr-o geografie şi o cultură într-altele, o neîncetată cercetare a celor mai bune modalități de expresie spațială, ornamentală şi de colaborare cu celelalte arte în vederea mai bunei reprezentări a misterului euharistic şi a simbolisticii creştine. De la bazilică la crucea greacă înscrisă, cu tipurile lor intermediare, este un drum lung de ,încercare şi eroare”, de piste aban-donate şi de polenizări încrucişate. 
Un arhitect realmente preocupat de soarta contemporană a arhitecturii creștine trebuie să vadă - deodată! - ambele fețe ale monezii: lucrul cu tradiția vie (lucrul cu arhetipurile, reiterarea acestora în circumstanțe, tehnici și materiale contemporane), dar în acelaşi timp cu experimentul. Biserica este vistiernic unei tradiţii de două ori milenare, în care trebuie să se îmbrace, mereu şi mereu, croindu-şi toalete mai potrivite pentru ea, ca mireasă şi, deopotrivă, ca Penelopă. Dar, în acelaşi timp, biserica este orientată către viitor, aşteptând cu nerăbdare un timp pe care îl știe „numai Tatăl”. Este şi motivul împodobirii bisericii orientate, în aşteptare. Această ,viitorime a privirii în trecut” ar putea fi definită astfel: „noutatea autentică e un senti-ment proaspăt al originarului, e reaşezarea liberă in spațiul tradiției". Retro-futurismul este unul dintre modurile acceptabile de „schimbare la față” a arhitecturii religioase, nu în sensul de producere în perpetuitate de imagini insolite, „noi”, pe care le-a introdus ca normă modernismul, ci în sensul investigării propriei tradiții (i.e. a locului şi geografiei sale, a grupului co-munitar, a limbii, a culturii şi, mai cu seamă, a religiei), în vederea reiterării acesteia. Insolitarea - pe care recontextualizarea permanentă a elementelor tradiţiei în circumstanţe geo-culturale, de materiale şi de semnificaţie noi o induce - este, de fapt, chiar modul de schimbare la faţă al arhitecturii dintot-deauna. Aceasta este sursa readecvării la contemporaneitate ..."

\section{Conceptul arhitectonic : înzidirea arhetipurilor ca} metaforă a convertirii (arca noetica)

Povestea $^{2}$ facerii bisericii din Alba Iulia se întinde pe un întreg deceniu, 2005-2015, inaugurarea locaşului fiind prevăzută în primăvara anului 2015, în preajma săbătorii Sfântului Ioan Evanghelistul, mai precis în ziua de 17 mai. În anul 2005 a demarat misiunea zidirii unei biserici pentru un cartier rezidențial în formare,

${ }^{1}$ Augustin Ioan, "Retrofuturism": cum se (mai) pot construi biserici astăzi?, disponibil pe site-ul http://www.arhiforum.ro/agora/\%E2\%80\%9Cretrofuturism $\% \mathrm{E} 2 \% 80 \% 9 \mathrm{D}-\mathrm{cum}$ se-mai-pot-construi-biserici-astazi (accesat la 12.08.2014).

2 Jan Nicolae, Arca noetica de la Alba Iulia, în „Arhitectura”, nr. 6, 2013, pp. 114-123. 
între Alba Iulia şi satul Miceşti, în direcția Apusenilor, spre oraşul Zlatna. Piatra de temelie a fost sfințită în ziua de 31 mai 2007 de către IPS Andrei Andreicuț, arhiepiscopul de Alba Iulia, în prezența starețului athonit Efrem Vatopedinul. Ctitorirea ei beneficiază de un parteneriat între parohia Cartier Nou (II) şi Fundaţia Transavia, regăsind tradiția interbelică a firmelor de succes implicate în proiecte de edificare a unor locaşuri ca mulțumire adusă lui Dumnezeu. Pentru a putea înțelege elementele esențiale ale programului iconografic al acestui locaş este nevoie să prezentăm mai întâi reperele conceptului arhitectural, care a fructificat o serie de excelente studii contemporane ${ }^{3}$, în contextul dezbaterilor în jurul construirii noii catedrale patriarhale, inclusiv concursurile de proiecte desfăşurate după 1990 în acest sens. Sfătuirea mea în calitate de preot al parohiei implicate în acest proiect cu o serie de prieteni implicați în domeniul artelor plastice a condus la o serie de contacte cu mai mulţi arhitecți români valoroşi din generații diverse: Şerban Sturdza, Radu Mihăilescu, Dorin Adam Ştefan. În cele din urmă, ideea chivotului post-modern ${ }^{4}$ a profesorului Dorin Ştefan, unul dintre cei mai apreciați arhitecți români contemporani, propusă pentru catedrala patriarhală şi publicată într-un album editat de Augustin Ioan, ne-a cucerit prin prospețimea şi distincția sa conceptuală. Beneficiarii potențiali, membrii comunității, au reacționat surprinzător de bine la elementele de noutate ale locaşului propus de arhitect: planul inedit, cu o trecere din bazilical în cruciform printr-o unduire progresivă a absidelor, care sugerează evoluția diacronică a edificiilor liturgice; eliminarea ferestrelor obişnuite şi înlocuirea lor cu o bandă de sticlă de jur-împrejur sub cornişă, pentru a crea un spațiu semi-întunecat; pridvorul într-un amplu arc de cerc la bază, tot cu o formă unduită; forma de elipsoid

${ }^{3}$ Ariadna Zeck, Occidentalizarea şi/sau laicizarea arhitecturii religioase din Tara Ro-mânească. 1780-1885, teză de doctorat, Bucureşti, 2000; Augustin Ioan, Arhiepiscopul Chrysostomos. Arhitectura în Biblie şi la Sfinții Părinți, Bucureşti, Pro Universitaria, 2013.

${ }^{4}$ Augustin Ioan (coord.), Concursuri pentru catedrala patriarhală ortodoxă: 1999-2002, București, Editura Noi Media Print, s.a. 
asimetric, descendent, a acoperişului şi de aripă de pasăre măiastră, care iese mult în afară, formând un spațiu de ocrotire deasupra pridvorului stilizat la maximum; şi, nu în cele din urmă, ideea centrală de spațiu iconic privilegiat, prin împodobirea zidurilor cu pictură exterioară, ca la ctitoriile rareşiene.

Locaşul propus are forma unui chivot-arcă, iar elementele sale de noutate au trecut în timp proba confruntării şi a recepției publice. Această metaforă arhi-tecturală a intrat, din fericire, foarte rapid în conştiinţa publică, iar eseurile dedi-cate ei în revistele Arhitectura $^{5}$ şi $I g l o o^{6}$ au avut efecte benefice. Proiectul a avut ocazia să fie prezentat de către Dorin Ştefan de mai multe ori în conferințe publice la Bucureşti (Institutul Mincu), Londra (ICR ${ }^{7}$ ) şi la Alba Iulia (Facultatea de Teologie). În anul 2009 mai multe imagini cu această biserică în stadiul inițial de după montarea structurii metalice au apărut într-o expoziție, ulterior fiind preluate în monografia profesională a arhitectului ${ }^{8}$. Unicatul arhitectonic a intrat devreme în vizorul hermeneutic al specialiştilor care i-au decriptat tâlcurile:

„Prin forma sa nuanțată, biserica amintește evoluția în timp a edificiilor de cult, de la simplitatea geometrică a planurilor bazilicale la complexitatea rezultată ulterior prin curbarea liniilor şi adăugarea progresivă a navelor şi a nişelor. Urmărind privirea credincioșilor, care se apleacă pentru a se ridica mai târziu, planul dreptunghiular de la baza construcției devine treflat înspre cornişă. În mod simbolic,

${ }^{5}$ Irina Rotaru, Biserica din Cartierul Nou - Alba Iulia, în „Arhitectura”, nr. 59, noiembrie, 2007, pp. 52-55.

${ }^{6}$ Interviu cu Dorin Ștefan realizat de Viorica Buică, Dorin Ştefan Birou de Arhitectură, în „Igloo”, nr. 72-73, dec. 2007 - ian 2008, pp. 40-60.

Dorin Stefan, 6 PROJECTS A CONTEXTUAL APROACH, METROPOLITAN UNIVERSITY IN PARTNERSHIP WITH THE ROMANIAN CULTURAL INSTITUTE IN LONDON (ICR), 1 NOVEMBER 2007, DEPARTAMENT OF ARHITECTURE AND SPATIAL DESIGN LONDON.

${ }^{8}$ Dorin Ştefan, Carte de bucate de arhitectură, grafica: Corina Gabriela Duma, red: Viorica Buică, Igloo, Bucureşti, 2009, pp. 306-311. 
construcția este structurată pe un modul de 12 , căci are 12 m lățime, 12 m înălțime și 24 lungime. Potrivit arhitectului, edificiul ar trebui să fie, înainte de toate, o cutie de rezonanță în interiorul căreia are loc misterul. Ca şi în cazul mânăstirilor de pe vremea lui Ştefan cel Mare, taina se continuă în exterior prin intermediul picturilor de pe ziduri. Iluminarea bisericii se face intenționat prin fante prevăzute sub acoperiș, în zona cornișei, pentru a nu afecta continuitatea pereților. Prelungirea frontală a acoperirii redă, prin unduirea sa lină, aripa unui înger. Intenția a fost de a crea un spațiu de adunare în care oamenii să se simtă protejați, în siguranță. (...). Ceea ce frapează în cazul acestui proiect este contrastul dintre simplitatea volumetriei şi bogăția ei la nivel simbolic" ".

Edificiul eclesial amalgamează în structura sa volumetria subtilă a unei nave-chivot cu simbolistica antropologică a convertirii. Receptacolul cruciform al locaşului devine un vas al luminii, un spaţiu al proslăvirii şi al transparenței unei frumuseți organizate iconografic, un palat al dumnezeiescului ospăț. Aripa îngerului ocrotitor al bisericii cheamă cu delicatețe în intrândul arhetipal al pridvorului, care comportă şi el o bogată simbolistică maternă (pântec, peşteră), paradisiacă / protologică (matrice protectoare) şi eshatologică (stânca vălurită, munte umbrit):,Pare pogorâtă din zidirile viitoare din Impărăția Cerurilor", remarca cu finețe un observator. Raportul dintre corpul puternic al locaşului şi acoperişul plutind pare să redea odihna sau umbrirea Duhului Sfânt peste Trupul lui Hristos.

Forma locaşului, asemănător unei chilii-paraclis athonite ${ }^{10}$, sugerează un spaţiu matriceal al renaşterii în Duh, o pasăre măiastră, o stâncă vălurindu-se spre eshaton, simbol al gestației creației celei noi, al unui spaţiu spiritualizat de misterul liturgic celebrat în interiorul său. Lectura acestei forme şi înțelegerea conceptului cer o

\footnotetext{
${ }^{9}$ Irina Rotaru, art. cit., p. 54.

${ }^{10}$ Vezi Costion Nicolescu, Et in Athos ego. Muntele sfințit, ediția a II-a, București Editura Sophia, 2013; ediţia I, Alba Iulia, Editura Reîntregirea, 2010.
} 
depăşire a comodităților vizuale. Biserica stă pe un gând divin care-i străbate pe toți cei implicați în facerea ei. Morfologic, aduce cu o chilie-paraclis şi, în acest sens retro-prospectiv, reprezintă o ilustrare minunată a conceptului paradoxal, oximoronic, de retro-futurism ${ }^{11}$, preluat de Augustin Ioan din avangarda interbelică şi folosit pentru acest edificiu eclesial:

„O interesantă ilustrare a paradoxalului concept de „retrofuturism" se construieşte într-o suburbie a municipiului Alba Iulia. Proiectul a fost realizat de cunoscutul arhitect Dorin Ştefan iar ,întruparea” lui a fost posibilă cu contribuția (aproape) exclusivă a unui important om de afaceri din zonă. Ideea care a stat la baza acestei insolite ctitorii este aceea că „străvechea noutate” a propovăduirii Bisericii este incompatibilă cu stereotipul de orice tip, inclusiv cel arhitectonic, iar depăşirea impasului tautologiei stilistice poate fi un semn al metanoiei în planul vieţii duhovniceşti a eclesiei drept-măritoare. "12

Metanoia se traduce estetic în minimalism decorativ şi maximalism simbolic. Arca noetica de la Alba Iulia este o cutie de rezonanță ${ }^{13}$ a misterului liturgic pascal dinlăuntru. De aici vin conjecturile biblice cu cubul arhetipal al cetăţii-templu eshatologic şi cele plastice cu cutiile-perspectivă, cu box architecture-a instalațiilor minimaliste ale lui Vlad Nancă (n. 1979) şi, nu în ultimul rând, cu morfologiile plastice brâncuşiene. Mai simplu spus, avem de-a face cu o kenoză arhitecturală, un experiment plin de prospețime în orizontul Tradiţiei, un Voroneț ori mai degrabă Arbore updatat. Între sursele primare trebuie amintite, în primul rând, celebra capelă

\footnotetext{
${ }^{11}$ Augustin Ioan, "Retrofuturism": cum se (mai) pot construi biserici astăzi?, comentariu preluat

pe forumul www.crestinortodox.ro/forum/showthread.php?t, (accesat în 29.08.2011).

${ }^{12}$ Ibidem.

${ }^{13}$ Jan Nicolae, Architecture. Une forme qui cloche, în „Courrier international”, 13 mars 2014, (www.arhitectura-1906.ro).
} 
Ronchamp $^{14}$ (1950-1955) a lui Corbusier (1887-1965) şi "chivoatele"15 iconologului român Sorin Dumitrescu (n. 1946), locaşul fiind din capul locului rezultatul confluenței unor mari spirite şi al unei curajoase sinteze simbolice. Dacă despre capela lui Corbusier s-a spus că este plină de contradicții arhitecturale, acest lucru este valabil şi pentru biserica proiectată de Dorin Ştefan: este în acelaşi timp pătrată şi ro(tun)dă, elansată şi îndesată, joasă şi înaltă. Ea are un plan simplu, vast şi deschis în exterior, dar, odată intrat înlăuntru, ea devine un mic loc de reculegere de o măreție liturgică împărătească. Albul strălucitor al zidurilor exterioare sugerează haina de mireasă a Bisericii, ilustrând totodată un principiu comun lui Corbusier şi spiritelor înrudite, pentru care emoția arhitecturală este jocul savant, corect şi măreț al volumelor asamblate sub lumină. Lucrarea luminii este mai sensibilă în interior, unde, prin pătrunderea sa subtilă în edificiu, contrazice greutatea şi masivitatea zidurilor, semnalând curgerea iconică a dumnezeieştii Dezvăluiri.

Într-un scurt eseu dedicat poeticii arhitecturale, Radu Negulescu afirma că, în spaţiul românesc, biserica de la Alba Iulia proiectată de Dorin Ştefan reprezintă diferența ${ }^{16}$, confirmând gândul originar de recuperare a unei creativități eliberate de sterilitatea mimetismului care răzbate într-un gând minunat al Părintelui Sofronie Saharov de la Essex (1896-1993), ucenicul şi moştenitorul spiritual al Cuviosului Siluan Athonitul (1866-1938) exprimând un adevăr comun atât poeticii duhovniceşti cât şi celei arhitecturale: „O, cât aş dori ca voi toți să deveniți poeți! Fără o insuflare creatoare este

${ }^{14}$ Daniele Pauly, Le Corbusier: La Chapelle de Ronchamp, Basel, Birkhauser, 1997; Ezra Stoller, The Chapel at Ronchamp, New York, Princeton Architectural Press, 1999.

${ }^{15}$ Sorin Dumitrescu, Chivotele lui Petru Rareşs şi modelul lor ceresc, București, Editura Anastasia, 2003.

${ }^{16}$ Radu Negulescu, Text, în Dorin Ştefan, „Carte de bucate de arhitectură”, grafica: Corina Gabriela Duma, red: Viorica Buică, Igloo, Bucureşti, 2009, pp. 304-305. 
greu să-ți petreci o singură zi aşa cum s-ar cuveni creştinului" "17. În chip minunat, arca-chivot de la Alba Iulia seamănă întrucâtva cu cea a mânăstirii Sf. Ioan Botezătorul de la Essex, ctitoria aceluiaşi Părinte Sofronie, iconar şi artist plastic, care a trecut cu toată pasiunea sa de la arta picturii la arta îndumnezeirii.

Odată cu publicarea unor texte însoțite de fotografii ale şantierului bisericii o parte din acestea au fost preluate pe web-site-ul american Pinterest, la capitolul vizual Religious Architecture.

Modul în care acest locaş a fost realizat, prin conjugarea mai multor slujiri (ctitor, preot, arhitect, constructor, pictor, sculptor, pietrar, textilist ş.a.) prin pronia divină, arhitect, pictor, sculptor, reprezintă în sine o slujire rațională, potrivită Logosului, pentru convertirea lumii prin frumusețea Jertfei Logosului înomenit. Locaşul întruchipează şi îşi asumă morfologic şi iconologic misiunea convertirii prin strălucirea frumuseții Logosului: „De la Hristos încoace nu mai rămâne nici o altă preoție sacerdoțiu decât cea care poate oferi o «slujbă cuvântătoare un cult rațional» (Romani 12, 1: latreia logikē), adică o ofrandă şi o cinstire conforme logos-ului care ne constituie după chipul şi asemănarea Logosului Însuşi, «venit săşi înfigă cortul printre noi» (Ioan 1, 14). Această jertfă pune în joc ceea ce are omul mai intim apropiat de Dumnezeu, puterea sa de decizie. Preoția / sacerdoțiul lui Hristos nu stă decât într-un singur act: realizarea voinței Tatălui. Pe scurt convertirea sau întoarcerea. (...). Dar convertirea se caracterizează prin universalitatea insistenței sale: e o convertire a totului - în mine, în noi şi în lume - la Tatăl, în Fiul, prin Duhul. Preoția / sacerdoțiul botezaților îşi manifestă caracterul împărătesc în această singură sarcină, care se confundă cu cea a lui Hristos şi se confirmă în ea: recapitularea în $\mathrm{El}$ a tuturor lucrurilor (Efeseni 1, 10; 1 Corinteni 15, 28). E vorba de a face cosmică liturghia convertindu-ne până acolo încât să convertim şi lumea. Cum Biserica nu constituie decât decât avansul acestei convertiri de-a lungul epocilor şi culturilor, nimic în Biserica pe care

${ }^{17}$ Părintele Sofronie, Cuvântări duhovniceşti, trad. rom. Ierom. Rafail Noica, Alba Iulia, Editura Reîntregirea, 2004, p. 292. 
o constituie acestea nu depăşeşte demnitatea supremă şi împărătească a preoție sacredoțiului botezaților, care nu datorează nimic nămănui, ci totul lui Hristos" 18

Arca noetica de la Alba Iulia propune o convertire radicală în veacul nihilismului printr-o poetică şi o apologetică $(1$ Petru 3,15$)$ a frumuseții, prin dezvăluirea raționalității profunde a iubirii trinitare, mai puternică, mai tainică şi paradoxală, decât rațiunea speculativă ori cea calculatorie, specifice metafizicii şi ştiințelor ${ }^{19}$. Dincolo de ispita diabolizării facile a veacului ori a izolării, Logosul cuvântă prin aceste ziduri-membrană, în acord cu gândul ctitoricesc, rezonanța muzicii tainei, după o rânduială a frumuseții.

\section{Legătura între conceptul arhitectural şi cel iconografic: o trecere de la arhe-tip la arhe-chip sau articularea teologică a arhetipologiei ioaneice}

Arhitectura nu ar fi completă fără conceptul teologic şi fără cel iconologic. Liniile de forță ale conceptului arhitectural au cerut o adecvare iconografică: pictorul bisericesc Ioan Popa a realizat un proiect iconografic, în colaborare cu preotul paroh, cu un caracter catehetic şi euharistic pronunțat, coerent şi liturgic în abordare, apreciat de o serie de teologi remarcabili şi oameni de artă care au vizitat şantierul bisericii. S-a ținut cont de condiționările date de dimensiunea pereților laterali, care se pretează la împărțire în patru registre iconografice, dar şi de forma de pâlnie a absidiolelor, care se potrivesc ,genetic" la cele două scene centrale „fluide” ale Botezului şi Cincizecimii, menite să înfăţ̧şeze Biserica drept cristelniţă a universului, cenaclu-potir euharistic deschis focului divin. Proiectele au constituit doar reperele inițiale, amorsări ale abordării; conceptul final susținându-se pe 0 temelie teologică amplă, imaginea

18 Jean-Luc Marion, Inalta demnitate a sărmanilor botezati, în Jean-Luc Marion, „Despre raționalitatea Revelației şi iraționalitatea credincioșilor”, trad. rom. Maria Cornelia Ică jr., Sibiu, Editura Deisis, 2015, pp. 95-97.

${ }^{19}$ Ibidem, p. 35. 
emblematică fiind în cele din urmă cea de Anastasis baptismal, adică imaginea Pogorârii la iad, la mise en abîme, kenoza maximală, misterul pascal abordat în toată cuprinderea sa: Botezul şi Euharistia ca Paşte al Bisericii, trecerea-salt a umanității şi a făpturii întregi în cer, dincolo de hotarele firii (spațiu, timp, materialitate, pătimire).

Treimea ioaneică binecuvântată. Modul în care aceste registre sunt împărțite pune accentul pe lectura tipologică şi liturgică a Scripturilor în cheie pascală, recognoscibilă în paremiile iconice ale marilor praznice ale Teofaniei şi Paştilor, în primul rând în lecturile vetero-testamentare din Sâmbăta Mare, situându-se echilibrat între narativ şi diagramatic, între tipologie, teologia semnelor iconice şi muzicale. Conceptul teologic în care se încadrează locaşul nostru din punct de vedere arhitectural şi iconologic este acela de arca noetica (pascală); acest concept ține cont de întreita dimensiune pascală a Bisericii: baptismală, euharistică şi profetică (martirică, ioaneică sau logosică), întruchipată în Sfinții Ioan Botezătorul (pecetea profeției ori îndemnul metanoic), Ioan Teologul (pecetea Evangheliei Logosului) şi Ioan Hrisostomul (pecetea predicii ca actualizare profetică a Cuvântului), ocrotitorii acestui locaş, alături de Sfinții Mucenici Brâncoveni $(\dagger 1714)$, hramul de temelie, îndreptățit prin patronajul spiritual şi material al voievodului Constantin Brâncoveanu asupra Mitropoliei Ortodoxe a Transilvaniei de la Alba Iulia şi prin jubileul tricentenar al martiriului în chiar anul terminării lucrărilor, 2014. Imaginea Sântioanilor reprezintă un blazon al Logosului ori, tradus în termenii culturali ai postmodernității, o pecete a raționalităţii comunicaționale $^{20}$, un sigiliu al nobleții catehetice.

În plus, proiectul iconografic ales pune în joc o polaritate esențială între cele două abside, cea între apă şi foc, rezolvată în absida altarului în figura monumentală a Orantei (foc în apă, cristelnița-potir, ilustrată prin deschiderea brațelor, semn al rugăciunii roditoare). Aceasta reprezintă axa hermeneutică a întregului edificiu. Apoi, fiecare latură are propria sa noimă iconică: cea din dreapta, raportul tematic şi iconologic al apelor primordiale, al celor

${ }^{20}$ Ibidem, p. 37. 
baptismale şi eshatologice; iar cea din stânga, raportul focului Duhului cu teofaniile vechi-testamentare şi cu „oamenii de foc”, purtători ai acestor descoperiri dumnezeieşti (Moise, Ilie, Elisei, Iezechiel, Isaia). Jocul hermenutic al polarităților foc-apă se regăseşte pe toată desfăşurarea iconică a celor doi pereți laterali ca expresie în oglindă a celor două faceri, a lumii şi a Bisericii, şi a corelatelor antropologice, Întruparea şi Îndumnezeirea.

A existat un proiect inițial focalizat pe un tip de iconografie diagramatică ${ }^{21}$, dar acesta a fost înlocuit în proiectul final printr-o iconografie tipologică şi simbolică, inserată pe ideea esenţială a unei cutii de rezonanță a misterului liturgic, a unui spaţiu metaforă vie a pulsaţiei liturgice şi diacronice (Hristos, Inima şi Capul Bisericii, ca în teologia Sf. Nicolae Cabasila). Pictorul Ioan Popa (n. 1976) a răspuns în detaliu problemelor şi întrebărilor puse de arhitect Ana Elisabeta Botez, legate de soluțiile plastice alese în duhul unei înnoiri cuviincioase şi raportul lor cu conceptul teologic de arca noetica, dezvoltat de preotul paroh:

„Formulele prezente se datorează în primul rând configurației arhitecturale, constrângerilor desfăşurării celor patru pereți simpli cu „pâlniile " pe care le cuprind și a tavanului atipic, care se împlinește cu o cupolă fără deschideri prin care lumina să pătrundă. S-a apelat în chip firesc la predecesorii din cadrul Tradiției şi la exemple similare. Un monument de referință a fost și rămâne Sant'Angelo in Formis, lângă Caserta (Napoli), monument cu un plan arhitectural de tip bazilical şi o pictură de factură bizantină cu elemente romanice (sec. XI). Era un reper forte, din care au început să ia naştere primele schițe şi studii dedicate bisericii de la Alba Iulia. S-au formulat mai multe variante, în care permutările la nivelul scenelor erau la ordinea zilei. Elementul de noutate inițial era o lectură de tip teologic, nu cronologic, narativ. Consta în lecturi și aprofundări ale troparelor şi paremiilor, în special la marile praznice, materializate în dispuneri pe patru registre orizontale generate de proporțiile firești raportate la înălțimea şi volumul edificiului. Acest tip de dispunere pot să afirm că este preluat, însă sub o formă mult mai coerentă, în care

${ }^{21}$ Vezi $O$ altfel de biserică la Alba Iulia, interviu realizat de Viorica Buică cu Sorin Dumitrescu, în „Igloo”, 118, (2011), pp. 14-15. 
cronologicul episoadelor importante din viaţa Mântuitorului se derulează pe un ax median, de forță, susținut şi completat deasupra şi dedesupt de două registre cu prefigurări vechi-testamentare. La nivelul exprimării plastice, tuşa vibrată şi spontană a pensulei, îndrăzneala la nivel compozițional şi lucrul lăsat neterminat, proaspăt, sunt câteva elemente de ținută. Am evitata formulările abstractizate, neobișnuite şi provocatoare, tipul de speculație teologică, scenele-cheie şi întreg eşafodajul conceptual să nu fie perceput ca un discurs de simeză, personal şi elitist, inaccesibil credincioşilor în sensul revelării tainelor Împărăției și comunicării catehetice a mesajului biblic.

În acest sens am căutat și o alternativă la redactarea plastică a tavanului. Un plan orizontal de asemenea dimensiuni este din start destinat decorativului. Orice abordare figurativă devine forțată şi grotescă. Mai rămânea soluția unei formule simbolice, cu suficient mesaj teologic şi de mare forță vizuală. Geometria cercului care include două pătrate suprapuse, generând un octo-gon, însuflețit de mişcarea şi cântarea celor opt heruvimi şi serafimi, dau imaginea reprezentării Imnului Heruvic, întărit prin textele-cheie care au şi rol decorativ, ornamental. Soluția auririi întregii suprafețe rămâne provocarea compoziţională şi riscul cel mai mare din întregul spaţiu desfăşurat.şi abia la finalul lucrării se poate evalua raportul plin-gol şi reflexul auriu răsfrânt pe suprafața pereților.

Cei patru pereți laterali ai edificiului cuprind scene ce se constituie într-un întreg în jurul celor patru teme pivot: la est, în altar, Maica Domnului a Semnului, în picioare cu mâinile întinse de tip orantă, sub forma unui potir ce conține în pântec pe pruncul Iisus Emanuel, încadrat într-un clipeu de văpaie nemistuită, preînchipuind Sfânta Împărtăşanie; flancul nordic desfăşoară profeții vechi-testamentare ce se împlinesc în scena monumen-tală ce umple absida stângă - Facerea Bisericii, Pogorârea Duhului Sfânt; absida peretelui sudic primeşte scena Pogorârii la Iad, o cristelniţă baptismală în care, în revărsarea apelor primordiale, Mântuitorul imerge în tenebrele iadului. Pe lângă funcțiunea catehetică, textul este inserat şi ca 0 componentă decorativă, austerităţii edificiului dăunându-i 0 ornamentică clasică, vegetală."22.

${ }^{22} \mathrm{O}$ prezentare succintă a programului iconografic se va putea vedea în curând, într-un text inedit, la Ana Elisabeta Botez, The Noetic Ark of Alba Iulia: When 
Aşadar, proiectul iconografic final vine $\mathrm{cu}$ o serie de contrapuncte liturgice şi de rezolvări plastice precum aurirea tavanului care izbuteşte, prin foița de aur, salvarea ambianței luminoase a spațiului interior, opțiunea având rațiuni teologice (aurul ca simbol al luminii increate etc.), dar şi practice, de oferire a unui cadru amplu imaginii inelului iconologic format din copolă (Pantocrator), tambur (Liturghia cerească) şi tavan (Heruvikon şi Trisaghion). Ambianța luminoasă este astfel îmbogățită, iar extinderea cerimii aurite a tavanului în exterior, sub streaşina acoperişului, conferă o anume prețiozitate locaşului, arvunind proslăvirea liturgică a credincioşilor încă din pridvor. Absida altarului dă monumentalitate şi măreție de catedrală locaşului, fiind un element forte al programului iconografic care susține conceptul de arca noetica, cu componenta ei profetică, baptismală si euharistică, Maica Domnului fiind deopotrivă prora eshatologică a Bisericii, cristelniță, potir, catarg şi arcă a mântuirii.

Anvergura teologică şi plastică la care a fost plasat dintrunceput acest proiect, prin colaborarea temporară cu Sorin Dumitreescu, datorează, în cele din urmă, enorm pictorului Ioan Popa, un artist tânăr care are deja în palmares câteva lucrări de referință (biserica Sfinții Mucenici Brâncoveni a Spitalului „Grigore Alexandrescu", biserica mănăstirii Afteia), o experiență internaţională (Cipru, Italia, Muntele Athos) şi o capacitate de asumare viguroasă a Tradiției care evită dogmatizarea artei în pofida icoanei (L. Uspensky). El a dovedit la Alba Iulia o deschidere minunată şi fertilă către o înnoire iconografică. Conceptul de „chivot mediatic" ${ }^{\text {"3.3 }}$, dezvoltat inteligent la vremea potrivită de iconologul Sorin Dumitrescu, a lăsat locul celui originar de arca noetica. În cele din urmă, proiectul iconografic final este unul aflat evident în matca Tradiției şi atent la moştenirea iconografică ecumenică a primului

Innovation Is the Standard Bearer of Tradition, în Augustin Ioan, volum în pregătire dedicat arhitecturii eclesiale românești după 1989, București, 2015.

${ }^{23}$ Sorin Dumitrescu, Chivotul mediatic de la Alba Iulia. Analiză de caz - studiu iconologic - prezentare iconografică, în ,Igloo", 124, (2012), pp. 35-40; Biserica in Cartierul Nou, pe site-ul www.arhiforum.ro/node/ 2527. 
mileniu creştin, autorul lui dovedind voinţa şi capacitatea de a-l duce la bun sfârşit spre slava lui Dumnezeu şi bucuria oamenilor.

Volumul mare de text se leagă de funcțiunea catehetică a iconografiei, dar şi de cea decorativă, specifică ortodoxiei latine, sugerată prin genul de literă şi de scriere alese. Între cele două abside laterale, ca între doi poli tematici ori mosoarele unui papirus ori manuscris liturgic şi exegetic, se desfăşoară rotulus-ul sau volumenul Împărăţiei, mesageria iconică şi logosică a Împărăţiei luminii celei neînserate, Arhe-Chipul şi Arhi-Textul. Lipsa unor împărțiri clasice a scenelor prin registre sau delimi-tări grafice stricte sugerează o unitate iconică şi o participare a semnelor la aceeaşi realitate tainică. În acelaşi timp este sugerată o recapitulare în Hristos a semnelor şi simbolurilor, între $\alpha$ şi $\omega$, încă din imaginile executate în exterior. Pecetea iconică centrală o reprezintă mega-icoana mandylion-ului de deasupra intrării, care sugerează o concentrare sau focalizare teologică, taborică şi eshatologică pe Faţa Domnului şi pe imaginea unei procesiuni de intrare a credincioşilor împreună cu îngerii în cer, idee exprimată explicit prin textul redat deasupra din rugăciunea intrării mici („Stăpâne Doamne, Dumnezeul nostru, Cel ce ai aşezat în ceruri cetele îngerilor şi ale arhanghelilor spre slujba slavei Tale, fă ca împreună cu intrarea noastră să fie şi intrarea sfinților îngeri, care slujesc împeună cu noi şi împreună slăvesc bunătatea Ta. Binecuvântată este intrarea sfinților Tăi, totdeauna, acum şi pururea şi în vecii vecilor") şi chinonicul Sfintei Mahrame, inserat în pisanie (,Întru lumina slavei Feței Tale, Doamne, merge-vom în veac. Aliluia"). Faţa iradiantă a Domnului contrastează cu albul pereților exteriori, sugerând că locaşul este un veşmânt sau înveliş al tainei. Fața Domnului este chipul Bisericii, iar reprezentarea ei pe faţada concavă de la intrare este legată şi de o metaforă corporală înrudită cu prospețimea ideii arhitecturale post-moderne de face-houses şi cu cea de personalizare a edificiului ${ }^{24}$. Fațada nu reprezintă o

${ }^{24}$ Augustin Ioan, Visul lui Ezechiel. Corp, geometrie şi spațiu sacru, București, Editura Anastasia, 1996, pp. 89-90: „Antropomorfismul şi, în sens mai larg, metafora şi simbolica asociate corpului devin degrabă proprietăţi ale arhitecturii postmoderne: apar celebrele face-houses ale lui Charles Jenks, Stanley 
extrovertire ideologică, ci o arvunire a experienței doxologice şi euharistice din interior, la care încearcă să convertească starea celui care intră în locaş, recuperând programatic dimensiunea eshatologică a cultului şi, în primul rând, a miezului său de foc, dumnezeisca Liturghie $^{25}$.

Deşi arhitectul concepuse exteriorul ca pe un continum neîntrerupt destinat unei desfăşurări iconografice ca la celebrele biserici moldave, forma specială a edificiului a cerut până la urmă o regândire, în sensul simplității arhetipale şi al reducerii la un esențial iconografic al semnelor puternice incluse în miezul unor texte liturgice alese din slujba târnosirii, desfăşurat sub forma unei benzi grafitti, pe trei şiruri, în partea superioară, sub fereastră: Fața Domnului (fațada), Mielul biruitor (altarul) şi heruvimii chivotului (lateral).

Programul iconografic sintetizează la nivel plastic căutările iconarului, iar la nivel tematic pe cele ale teologului. Botezul şi Euharistia, Paştele Bisericii, reprezintă o regăsire a vechii tradiţii catehetice exemplificate prin Sf. Chiril al Ierusalimului, reprezentat

Tigerman (Animal Crakers House), Takefumi Aida (Nirvana House), Robert Venturi (Brant House) sau Yamashita (care personalizează un edificiu conturând profilul clientului său în planul unuia dintre balcoane. (...) Postmodernismul, care exfoliază faţada, îşi permite să o (mal)trateze ulterior fără consecințe semnificative pentru spaţiul interior. Antropomorfismul postmodern, extrovertit, este superficial, atât la propriu, cât și la figurat".

${ }^{25}$ Karl Christian Felmy, Verdrängung der eschatologischen Dimension der byzantinischen göttlichen Liturgie und ihre Folgen, în Idem, Diskos. Glaube, Erjahrung und Kirche in der neuen orthodoxe Theologie. Gesammelte Aufsätze, hrsg. Von H. Ohme und J. Schneider, Erlangen, 2003, trad. rom. Picu Ocoleanu, Inlăturarea dimensiunii eshatologice a Dumnezeiştii Liturghii bizantine şi urmările ei, în Idem (ed.), Teologie şi spiritualitate în gândirea Sfântului Maxim Mărturisitorul, Craiova, Editura Mitropoliei Olteniei, 2009, pp. 78-89; Jan Nicolae, «...spre liturghia slavei Tale». Criza mistagogiei in Biserică de la catehezele mistagogice la comentariul liturgic -Mystagogia Sfântului Maxim Mărturisitorul şi lectiile ei catehetice-, în „Libertate şi responsabilitate. Inițiative şi limite în dialogul religios", Alba Iulia, Editura Reîntregirea, 2009, pp. 488-513. 
în altar, deasupra proscomidiarului, iar imaginea baptsimală a Pogorârii la iad o recuperare a teologiei baptismale primare, iudeocreştine, în care iadul prelungește genunea apelor primordiale luând alura unei cristelnițe ${ }^{26}$, reafirmându-se că, prin Moise, Israelul cel vechi a avut parte tipologic de Botezul şi de Euharistia viitoare (1Corinteni 10). De altfel, cheia întregului program iconografic o reprezintă fructificarea dimensiunii ontologice a tipologiei biblice, rezumată de Părintele Ioan ică jr astfel în „Canonul Ortodoxiei”: „tipologia biblică este nu doar un sistem hermeneutic, ci unul ontologic. Şi, într-adevăr, pentru gândirea biblică tipologia este ontologică, iar ontologia este tipologică. Aceasta înseamnă că evenimentele Vechiului Legământ participau în mod figurat, dar foarte real, la evenimentele Noului Legământ, şi ambele legăminte şi cultul lor prefigurează real o Realitate cerească deplină, în acelaşi timp viitoare şi eternă. Sfântul Maxim va exprima gradele acestei participări tipologice astfel: Vechiul Legământ este umbra (skia), iar Noul Legământ este icoana (eikon) unei realități (aletheia) eshatologice şi eterne: Împărăția lui Dumnezeu. Tipologia nu este însă doar istorică, biblică, ci şi liturgică. Liturghia şi cultul mediază şi ele între două serii de fapte: pe de o parte, un eveniment mister irepetabil sau etern cu valoare de realitate originală (aletheiamysterion mysterium-typos); iar, pe de altă parte, un rit simbol repetabil în timp cu valoare de copie imitație figurativă (eikon mimesis-symbolon sacramentum-antitypon)" ${ }^{\prime 27}$. Un text minunat din Păstorul lui Herma (sec. II) face conexiunea între Anastasis (katabasis) şi Botez, aşa cum sunt îngemănate ele iconografic la Alba Iulia: „.... că omul este mort înainte de a purta pecetea Fiului lui Dumnezeu; dar când primeşte pecetea, leapădă moartea şi primeşte

\footnotetext{
${ }^{26}$ Vezi referinţele baptismale la Jean Daniélou, Biserica primară (De la origini până în secolul al treilea), trad. rom. George Scrima, București, Editura Herald, 2008, p. 99 și la Ilarion Alfeyev, Hristos, Biruitorul iadului. Pogorârea la iad in perspectiva ortodoxă, trad. rom. Cristian Vâjea, București, Editura Sophia, 2008, pp. 18-20.

27 Ioan Ică jr, «...tipologia biblică devine alegorie mistericăł», în Canonul Ortodoxiei, vol I, Sibiu, Deisis/ Stavropoleos, 2008, pp. 305-306.
} 
viața. Pecetea este, aşadar, apa; morții se coboară în apă şi se ridică vii... aceştia sunt Apostolii şi învățătorii, cei care au predicat numele Fiului lui Dumnezeu; aceștia, adormind, în puterea şi credința Fiului lui Dumnezeu, au predicat şi celor mai înainte adormiți şi le-au dat lor pecetea predicii. S-au pogorât, aşadar, cu ei în apă şi iarăşi s-au ridicat; dar aceştia s-au pogorât vii şi vii s-au ridicat; ceilalți însă, cei mai înainte adormiți, morți s-au pogorât şi vii s-au ridicat. Prin aceştia, dar, au dobândit viață şi au cunoscut numele Fiului lui Dumnezeu; de aceea s-au şi ridicat împreună cu ei..."28.

De altfel, imaginea rolului soteriologic excepțional, universal, al Pogorârii şi al propovăduirii la iad a lui Hristos către „întregul Adam", pregătite de Sf. Ioan Botezătorul, potrivit tradiției imnografice, este înfățişată ca o plinire în Liturghia Sf. Vasile cel Mare, celebrată inclusiv în Sâmbăta mare: „Şi pogorându-Se prin Cruce în iad, ca să plinească toate ale Sale, a nimicit durerile morții. Şi înviind a treia zi şi cale făcând oricărui trup la învierea cea din morți, că nu era cu putință a fi ținut în stricăciune Începătorul vieții, făcutu-S-a pârgă celor adormiți, Întâi-Născut din morți, ca să fie El Însuşi Începătorul tuturor întru toate" ${ }^{" 29}$. Cu alte cuvinte, imaginea baptismală a Pogorârii la iad de la Alba Iulia reprezintă un manifest teologic, o punere duhovnicească în abis a teologiei şi a predicii, în sensul în care Hristos înviat este o Predică vie: „Pentru lumea secularizată în care trăim «iadul» este un cuvânt «de groază» care face parte mai degrabă din terminologia hollywoodiană, decât a vieții reale. Pentru omul creştin însă, iadul este o realitate de la care, de multe ori, porneşte chiar viaţa noastră duhovnicească. Şi dacă pentru lumea secularizată «iadul» este un capăt de drum, pentru lumea creştină iadul poate fi chiar începutul unui drum a cărui continuare este, paradoxal, bucuria." ${ }^{30}$.

${ }^{28}$ Păstorul lui Herma, Pilde 9, 16, apud. Ilarion Alfeyev, op. cit., pp. 19-20.

29 Dumnezeiasca Liturghie a Sfântului Vasile cel Mare, în „Litughier”, Bucureşti, Editura I.B.M.B.O.R, 2000, pp. 228-229.

${ }^{30}$ Maica Siluana, Cu Hristos te întâlneşti, mai întâi, în iad. Convorbiri despre disperare, căutare, durere şi mântuire, Bucureşti, Editura Lumea credinței. 2013. 
Conexiunile plastice şi tematice se continuă la nivelul întregului edificiu între iconografie, candelabru, iconostas, uşa de intrare şi uşa altarului. Mistagogul inițierii în taina programului iconografic este Duhul Sfânt Însuşi, reprezentat în cele două clipee superioare din mega-icoanele din absidiolele laterale, ca Cel care urzeşte creația cea dintâi şi care pecetluieşte creația cea nouă, dar înfățişat plastic şi ca „pasăre în văzduh” izvorâtoare de lumină, în formula candelabrului-tabernacol al luminii, prezent in mijlocul bisericii, Paraclet sfințitor şi Trezorier euharistic al Bisericii, după modelul unor bazilici romanice, întruchipând un simbol paleocreştin: "Porumbelul nostru locuieşte într-o casă simplă, întotdeauna pe loc ridicat, descoperit şi în plină lumină"31.

În acest semn se developează taina locaşului proiectat de Dorin Ştefan, un spirit brâncuşian, creator de arhitectură pură pentru care este valabilă deplin afirmația mentorului său că ,arhitectura este sculptură locuită" ${ }^{\prime 32}$. Plutirea acoperişu-lui peste cubul (dublu al) corpului fizic al edificiului sugerează odihna Duhului peste Trupul lui Hristos, dar şi odihna păsării-suflet peste omul universal, iar în interior sălăşluirea, strălucirea (din adâncuri şi din înalturi) şi străfulgerarea epicletică a Duhului în viața liturgică. $\mathrm{Cu}$ alte cuvinte, avem parte de o prezență a unui „distilat de Brâncuşi" ${ }^{33}$ în arhitectura eclesială de la Alba Iulia, o raportare creativă între sculptura brâncuşiană a arhetipurilor şi arhitectura arhetipal-iconică dorinştefaniană, care oferă un răspuns tendințelor localiste şi autohtoniste mimetice, la care ne ajută şi considerațiile lui Augustin Ioan:

„Arhitectura ortodoxă a devenit, aşadar, în o mie de ani, fundamental alta, schimbându-şi fạta. Ce a rămas imuabil? Doar arhetipurile sacre, fie că ele sunt modele îngerești, cum

${ }^{31}$ Tertulian, Adversus Valentinianos, III, 1, apud Jean Daniélou, op.cit., p. 204. ${ }^{32}$ Dorin Ştefan în memoria lui Brâncuşi, interviu realizat de Viorica Buică, în .Igloo", 144-145, decembrie 2013 - ianurie 2014, p. 51.

${ }_{33}$ Ibidem, p. 52: „- Ce credeți că (mai) poate învăţa arhitectul contemporan din sculptura lui Brâncuși? (...) D. Șt: Sculptura lui Brâncuși «conține spațiu». Este în același timp şi o mare capcană să încerci să bagi funcțiuni într-o formă brâncuşiană. Brâncuşi trebuie distilat în arhitectură. (...)". 
presimțiseră Platon și profeții care văzuseră templul de aur al Ierusalimului ceresc, fie că sunt ele, arhetipurile, categorii apriorice ale conştiinței umane, cum ne spun mult mai încoace Jung și Cristopher Alexander. Ele, împreună cu o ştiință a epifaniei lor în materie, conformează arhitectura. Ele fac să se pogoare sacrul întru zidire, ele sunt icoanele arhitecturii, cele care mijlocesc între Dumnezeu şi ecclesia: nava bisericii, bolțile în cruce, axis mundi începând lumea și întâlnind cerurile sub cupolă, în centrul de sus unde veghează Iisus Pantocrator. (...) A doua întrebare retorică: este tradiția doar un îndreptar de forme datate istoric sau, mai degrabă, o sumă de principii virtuale, care pot fi actualizate mereu şi mereu, altfel la chip și totuşi la fel în duh?" ${ }^{34}$.

Există un mic contrast, un uşor contrapunct între arhitectură şi pictură care, după unii specialişti, face bine locaşului. Trecerea de la morfologia acestui unicat arhitectural la podoaba sa este una de la arhetipuri la arhe-tipologie iconică. Genului de arhitectură arhetipală şi fluidă creat de Dorin Ştefan i se potrivea conceptul diagramatic iniţial (2011), dar este pus în valoare la fel de bine de programul iconografic final, bazat pe teologia semnelor şi peceților (Maica Semnului, Semnul lui Iona, semnele şi numele hristologice între alfa şi omega), pe tipologia pascală, baptismală şi euharistică.

Prin renunțarea la împodobirea pereților exteriori cu frescă s-a dorit tocmai evidențierea sculpturalitătii fluide a corpului arhitectural, care intră în dialog creator atât cu arhitectura sacrală a lui Corbusier, cât şi cu arhitectura fantastică postmodernă a spațiilor fluide ${ }^{35}$. Se poate constata, de la primele imagini ale scheletului metalic al structurii bisericii până la cele din urmă, imaginea unei păsări, o adevărată epifanie a unei ființe fantastice, ivirea în peisaj şi arătarea unei dihănii nemaivăzute. $\mathrm{Nu}$ este altceva decât chipul Păsării

\footnotetext{
${ }^{34}$ Augustin Ioan, Visul lui Ezechiel..., p. 138.

35 Ibidem, p. 87: „Corpul - uman, animal sau al cutărei ființe fantastice - nu structurează arhitectura în același fel în care, bunăoară, spațiile fluide (flowing spaces) ale lui Saarinen de la TWA Terminal de la JFK Airport din New York mimează silueta unei păsări zburânde, ori în care spina arcuită a patinoarului Universităţii Yale, a aceluiași autor, este adeseori asemuită unei ființe spielbergiene din Jurassic Park".
} 
măiastre primordiale, al Duhului mereu surprinzător, prezent şi activ în facerea şi devenirea bisericii.

În acest sens, dacă ar fi să căutăm în universul brâncuşian un reper pentru spațiul liturgic imaginat de Dorin Ştefan, acesta ar fi legat de morfologiile plastice care propun dinamica luminii, a zborului şi a gândului în văzduhul unei libertăți maxime, precum în diferitele versiuni ale „Păsării în văzduh (spațiu)” şi ale „Domnişoarei Pogany”. Unul dintre cei care au exprimat cu profundă înțelegere arta brâncuşiană în orizontul unei priviri în materie cu ochii Duhului şi al transfigurării feerice a formelor a fost scriitorul Eugen Ionesco (1909-1994), a cărui mărturie ne ajută să facem legătura între sculptura vizionară a lui Brâncuşi şi arhitectura locuită de geniu plastic a lui Dorin Ştefan:

"În sine însuşi şi singur şi-a găsit el propriile modele, arhetipurile sculpturale. A fost vorba la el de o concentrare, de o purificare lăuntrică. El a privit şi în afară: nu tablouri, nu statui, ci arbori, copii, păsări în zbor, cerul sau apa. El a ştiut să surprindă ideea miş̧ării îndepărtînd orice realism particular în favoarea unui real universal. (...) Operele lui sînt figuri esențiale, imaginile concrete ale unor idei, expresia unui real universal antiabstract. Nimic nu e mai concret decît pasărea sa în zbor, formă dinamică palpabilă a dinamismului. (...) Brâncuşi s-a eliberat de orice particularism, după cum s-a eliberat şi de orice psihologism, pentru a ajunge la esențele concrete. (...) Opera lui Brâncuşi exprimă numai idei şi forme sculpturale. Ştim că poezia lui Mallarmé sau a lui Valery era o reflecție asupra poeziei. În mare parte, sculptura lui Brâncuşi este şi o reflecție despre sculptură; în acelaşi timp, o metodă pur sculpturală de a gîndi lumea, tradusă în forme şi linii de forță vii. (...) Începînd din 1907 (în Rugăciunea sa), ceea ce rămîne din afectivitate dispare datorită stilizării, oarecum bi-zantine, care transpune, integrează sentimentalitatea. La prima vedere, Oul seamănă destul de mult cu ,nou-născutul” în scutecele sale. Din 1910, Pasărea Măiastră a depăşit, de mult, în miraculos, pasărea realistă, nemiracu-loasă; ne mai 
putem da seama, poate, urmînd etapele simplificării sale, că $O u l$ are ca punct de plecare pe noul-născut; putem urmări şi stilizările dife-ritelor Domnişoare Pogany, pentru a ajunge la etapa ultimă, care este o îndrăzneață, feerică transfigurare, însă curînd, în măsura în care stilul este, oricum, anecdotă, Brâncuşi va depăşi stilizarea pentru a ajunge la un limbaj de dincolo de limbaj, de dincolo de stilul însuși. (...) Contemplând, în puritatea ei, Pasărea în spaţiu, sîntem uimiți de acuitatea viziunii sculpturale; ne mirăm de simplitatea ei şi ne mirăm de asemenea de faptul că n-am putut vedea ceea ce este evidența însăşi. Foarte surprinzătoare, de necrezut, aceste sinteze: folclor fără pitoresc, realitate antirealistă; figuri de dincolo de figurativ; ştiință şi mister; dinamism în împietrire; ideea devenită concretă, făcută materie, esență vizibilă; intuiție originară, dincolo de cultură, de academie, de muzee." ${ }^{\text {"36 }}$.

Aşadar, Brâncuşi a căutat în arta sa rațiunile plastice ale făpturilor, semin-țele de gând luminos răsădite din Mintea divină în adâncul lumii date spre păstorire omului ${ }^{37}$. Spațiul pur pe care Dorin Ştefan îl consacră misterului euharistic este unul care tinde spre o concretizare a dinamismului, a esenței zborului, spre această „feerică tranfigurare", calea către o transparență totală a luminii eshatologice, un loc destinat unei mistagogii a luminii nesfârşite, aşa cum el propune pentru celebrarea liturgică în biserica de la Alba Iulia şi pentru celebrarea estetică, contemplativă, a aceleiaşi taine, în cubul de sticlă de la Craiova, dedicat lui Brâncuşi, mentorul său.

\section{Desfăşurarea programului iconografic}

Mai întâi trebuie spus că spațiul generos, cu o suprafaţă de $1200 \mathrm{~m}^{2}$, dese-nat de arhitect în vederea unei experiențe a

\footnotetext{
${ }^{36}$ Eugen Ionesco, Note şi contranote, Paris, Gallimard, 1962, apud Tabart 1995 , pp. $105-109$.

37 †Daniel, Patriarhul Bisericii Ortodoxe Române, Brâncuşi. Sculptor creştin ortodox, Iași, Editura Trinitas, 2007.
} 
transparenței spirituale, se pretează la o amplă şi creativă desfăşurare iconologică, ca la vechile bazilici, în care Revelația biblică primea o bogată lectură catehetică şi iconică. Nu trebuie ascuns faptul că promotorii acestui program iconografic consideră acest locaş un manifest pentru regăsirea acestui tip de lectură iconologică a Scripturilor liturgice, într-o mlădiere plastică pe măsura unui autentic templu duhovnicesc, unde nu au loc crispările, rigiditatea, mimetismul.

Altarul Spaţiu sacru prin excelență, altarul, primeşte cicluri iconografice funda-mentale mai greu supuse schimbărilor tocmai pentru faptul că ele poartă amprenta ritualului liturgic ce se desfăşoară aici şi corespund simbolisticii acestei părți a locaşului de cult, temele predilecte fiind în strânsă legătură cu Taina Sfintei Euharistii. Datorită specificității arhitecturii, spațiul nu beneficiază de o absidă clasică sau compartimentări speciale, motiv pentru care altarul generează trei suprafețe verticale plane: una frontală, cu o desprindere evazată sub forma unei pâlnii de la bază către buza superioară, şi două laturi aparținând pereților laterali. Peretele frontal, aşadar, o înfățișează pe Maica Domnului a Întrupării, în picioare, în postura de orantă, ținându-l în dreptul pântecelui pe Iisus prunc cu-prins într-un clipeu, întreaga reprezentare având o statură monumentală, de circa şapte metri. Maica Semnului este flancată de două grupuri de câte trei arhangheli în picioare, în gest de închinare, înveşmântaţi în tunici bogat ornamentate, într-o desfăşurare muzicală, cu aripi în genul corzilor de harpă, purtând ripidele numelui sfânt şi praporii sfințeniei.

Registrul inferior cuprinde, în partea centrală, imaginea lui Hristos Mare Arhiereu, oferind prescura şi potirul pentru Împărtăşirea apostolilor, iar, în continuarea acestora, procesiunea Sfinților Ierarhi, cortegiu ce se desfăşoară spre extremități şi pe cei doi pereți laterali. Sfinții ierarhi țin în mâini filactere cu rugăciuni liturgice şi sunt orientați spre centrul euharistic. Astfel, pe flancul nordic, şirul începe cu Sf. Ioan Gură de Aur, Sf. Grigorie Teologul, Sf. Nicolae (chiar deasupra nişei proscomidiarului, semn al slujirii preotului paroh omonim), Sf. Chiril al Ierusalimului şi Sf. 
Arhidiacon Ştefan purtând macheta bisericii (un subtil omagiu adus diaconiei şi purtării de grijă a arhitectului Dorin Ştefan). Pe latura sudică, Sf. Vasile cel Mare, Sf. Ghelasie de la Râmeț (sec. XIV), Sf. Simion Ştefan (sec. XVII), Sf. Varlaam al Moldovei (sec. XVII), Sf. Antim Ivireanul al Ungrovlahiei (sec. XVII-XVIII). Sfinții ierarhi români au fost aleşi din raţiuni istorice şi culturale: Sf. Ghelasie personalizează rolul deosebit al mă-năstirii Râmeț din Munții Apuseni în istoria Bisericii transilvănene; Sf. Simion Ştefan, „sfântul cărturar al Transilvaniei", este chipul păstorului inteligent în vremurile prozelitismului calvin, patronul traducerii şi ediţiei princeps în limba română a Noului Testament (Bălgrad, 1648), întruchipând ideia înnobilării prin cultură; Sf. Varlaam, mitropolitul Moldovei, rămâne emblematic prin Cazania sa atât de iubită în Ardeal, iar Sf. Antim Ivireanul, mitropolitul lui Brâncoveanu, autorul celebrelor Didahii şi întemeietorul omileticii româneşti, întruchipează, prin toată activitatea sa, cea mai enigmatică şi mai rodnică personalitate a culturii române. Textele alese pentru filacterele ierarhilor sunt adevărate giuvaere literare, alese din operele pomenite mai sus, având legătură cu abordările teologice ale preotului paroh dedicate acestora ${ }^{38}$.

Suprafața dedicată scenelor de pe cei doi pereți laterali include patru registre suprapuse, astfel încât pe nord, în altar, avem scene vechi-testamentare de prefigurare a jertfei Fiului, mai precis Jertfa lui Noe şi a lui Avraam, apoi o amplă Cina de Taină, iar mai jos o abordare în imagini concentrate a momentelor simbolico-liturgice din slujba sfintei proscomidii: Naşterea Domnului, Răstignirea şi Iisus în mormânt, cu accent pe peştera Naşterii, pe sângele şi apa ce ies din coasta Mântuitorului. Spațiul destinat proscomidiarului reprezintă un omagiu adus Transilvaniei euharistice: pe frontonul baldachinului

\footnotetext{
38 Jan Nicolae (coord.), Mitropolitul Simion Ştefan. Sfântul cărturar al Transilva-niei, Alba Iulia, Editura Reîntregirea, 2012; Jan Nicolae, Omiletica brâncovenească şi medicina. De la "mreaja bogosloviei" la "meşterşugul doftoresc". Elemente de theologia medicinalis in opera Sfântului Antim Ivireanul, în "Tabor", an VII, nr. 10, octombrie 2013, Cluj-Napoca, 2013, pp. $13-32$.
} 
apare înscrisul ioaneic „Eu sunt Vița cea adevărată” (Ioan 15, 1), apoi scena centrală „Hristos Vița" ${ }^{\text {, }}$, cu un rol minunat în istoria sacramentală a românilor, însoțită de textul pascal „Veniți să bem din rodul cel nou al viței, al dumnezeieştii veselii ..."; pe pereții laterali, Iosua şi Caleb poartă strugurele Canaanului, iar pe exteriorul acestora veghează două figuri remarcabile ale telogiei euharistice româneşti care ne-au trecut pragul secolului XXI: Părintele arhimandrit Ioan $\operatorname{Iovan}^{40}$ (1921-2008), corespondentul Sf. Ioan din Kronstadt în spațiul românesc şi minunat mărturisitor al lui Hristos în temniţele comuniste, reprezentat în veşminte pascale, purtând un potir auriu, şi Părintele profesor Ilie Moldovan ${ }^{41}$ (1928-2012), profet al vieții, al „iubirii euharistice” şi al regenerării morale a neamului prin cuminecare, reprezentat cu o cruce-cunună a grâului, expresie plastică a etnicităţii euharistice şi a misiunii catehetice („Ieşit-a Semănătorul să semene sămânța sa"). Sub cele două figuri sunt redate textele ultimelor două strofe din celebrul poem „Cîntecul potirului" al lui Nichifor Crainic: "Şi iată potirul la gură te-aduce,/ Iisuse Cristoase, Tu jertfă pe cruce;/ Adapă-mă, sevă de sfânt Dumnezeu./ Ca bobul în spice şi mustu-n ciorchine / Ești totul în toate şi toate prin tine, / Tu, vinul de-a pururi al neamului meu. / Podgorii bogate ți lanuri mănoase, / Pământul acesta, Iisuse Cristoase, / E raiul în care ne-a vrut Dumnezeu. / Priveşte-te-n vie şi vezi-te-n grâne / Şi sângeră-n struguri şi frânge-te-n pâine, / Tu, viaţa de-a pururi a neamului meu".

39 Jan Nicolae, Iconografia Euharistiei: Hristos, vița cea adevărată şi vimul adevă-rului, Alba Iulia, Editura Altip, 2014.

40 Jan Nicolae, „Potirul este viața mea”. Părintele Ioan Cuminecătorul. Euharistie şi martiriu in viața unui preot român in inchisorile comuniste, în Mihai Himcinschi, Jan Nicolae (coord.), „Eucharist and Martyrdom from ancient catacombs to the communist prisons", ISSTA 2014, vol. I, Alba Iulia, Editura Reîntregirea, 2014, pp. 327-358.

${ }^{41}$ Ilie Moldovan, Ín Hristos şi în Biserică: iubirea euharistică generatoare de viață şi destin românesc, Alba Iulia, Editura Reîntregirea, 2011; Ilie Moldovan, Ioan Nicolae, Calendarul viu. Dialoguri euharistice intre generații, Alba Iulia, Editura Reîntregirea, 2007. 
Registrul iconografic inferior al naosului, destinat martirilor, mărturisitorilor şi cuvioşilor, pandant al discursului euharistic de la proscomidiar, îi include şi pe sfinții reînnoirii liturgice, filocalice şi euharistice ortodoxe Nicolae Cabasila, Nicodim Aghioritul şi Ioan din Kronstadt. Biserica cuprinde şi o podoabă în piatră în această zonă, înrudită cu cea a altarului, de care s-a ocupat Vasile Țiplea de la Cluj-Napoca.

Întregul ansamblu al altarului format din iconostas, proscomidiar şi uşa de ieşire a altarului stă sub pecetea teologiei euharistice şi a arhe-hristologiei ioaneice. Iconostasul acestei biserici a fost realizat cu simplitate şi rafinament de artistul plastic Virgil Scripcariu (n. 1974) şi se încadrează în aceeaşi orientare euharistică, partea de sus fiind în forma buzei unui potir, privit din profil, care-şi revarsă preaplinul în naos, iar întreaga sa elaborare va încerca să îmbine mai multe tipologii reconciliate euharistic în imaginea lui Hristos ca noua Catapeteasmă a Templului eshatologic ${ }^{42}$ (cf. Evrei 9) : potir, ecran mistagogic, viță (arbore) a lui Iesei, norul de martori, înălțimea sa fiind exact până la piedestalul de sub picioarele Orantei din absida altarului, dispus pe circa 4 metri. El întruchipează teologia catapetesmei euharistice din Epistola către Evrei, manualul de tipologie biblică prin excelență: „Drept aceea, fraților, având îndrăzneală, să intrăm în Sfânta Sfintelor, prin sângele lui Iisus, Pe calea cea nouă şi vie pe care pentru noi a înnoit-o, prin catapetesmă, adică prin trupul Său" (Evrei 10, 19-20).

Morfologia iconostasului lui Virgil Scripcariu se integrează desăvârşit în cea propusă de Dorin Ştefan, în acelaşi spirit minimalist, fiind roada unui dialog fertil şi admirabil între cei doi artişti. Icoanele catapetesmei au fost executate de pictorul Ioan Popa împreună cu soția sa, Camelia Popa, şi sunt cuprinse pe două etaje iconografice: în cel dintâi icoanele împărăteşti Hristos Invățător cu o viță de vie şi Maica Domnului cu Pruncul Iisus purtând un ciorchine de strugure (Weintrauben Madona), alături de icoanele de hram:

${ }^{42}$ Jan Nicolae, Dumnezeiasca Euharistie, catapeteasma zilei a opta, conferință
în cadrul Festivalului „Din dragoste pentru frumos”, Paris, 29 mai-1 iunie 2014. 
Sfinții Mucenici Brâncoveni şi Sfinții Ioani - Botezătorul, Evanghelistul şi Hrisostomul; etajul al doilea cuprinde praznicarul de tâmplă, iar deasupra icoana Hristos în slavă, trecând dincolo de catapeteasma zilei a opta. La bază, dedesubtul celor patru icoane ale primului registru iconografic al iconostasului, vor fi stilizate patru simboluri aviforme: pelicanul (Hristos), cloşca (Biserica, după modelul de la biserica ierusalimiteană Dominus flevit), phoenix-ul (Brâncovenii) şi vulturul (Ioanii). Reprezentările simbolice legate de pasăre şi zbor reprezintă un omagiu adus finanțatorului, a cărui primă fermă de păsări Transavia a fost în perimetrul alocat acum bisericii. În acelaşi timp, ea sugerează trecerea de la simbol la icoană, aşa cum unduirea pereților conține sugestia trecerii de la bazilică la spațiu cruciform.

După mai bine de 10 ani de rugăciune şi cinstire a Sfinților Brâncoveni, aceştia au răspuns în chip minunat, devenind gazdele icoanelor catapetesmei în Galeria Cuhnia din cadrul Palatul Brâncovenesc de la Mogoşoaia, reunite într-o expoziție pascală „Catapeteasma euharistică - prag pascal al Împărăţiei”"43, vernisată în după-amiaza zilei de Bunavestire, de către preotul paroh împreună cu amfitrioanele brâncoveneşti Doina Mândru şi Mădălina Mirea, stârnind interesul televiziunii publice (TVR1, Viața spirituală) care a prezentat un amplu reportaj. În joia Săptămânii luminate, icoanele au fost aduse de la Mogoşoia la Alba Iulia, icoana Sfinţilor Brâncoveni fiind întâmpinată cu mare cinste, cântându-se imnul pascal. Ar mai trebui adăugat aici faptul că există un registru iconografic superior al acestei catapetesme pe partea din lăuntrul altarului, dezvoltat într-o amplă desfăşurare teologică: pandantul icoanei „Hristos în slavă” este imaginea Hristos-ul Preascumpului Sânge, după un model

${ }^{43}$ Programul Muzeului Palatelor Brâncovenești, Expoziție pascală, 25 martie15 aprilie 2015: „Realizarea icoanelor expuse la Palatele Brâncoveneşti a avut loc sub îndrumarea teologică a părintelui Jan Nicolae și a reunit o serie de artiști care au concurat pentru realizarea unui spațiu eclezial impresionant. Pictura, într-o viziune plasată sub semnul inovaţiei cuviincioase, aparține lui Ioan Popa, ca şi icoanele din maiestuosul iconostas din lemn de stejar, sculptat nobil şi auster de Virgil Scripcariu“ (Doina Mândru, Mădălina Mirea). 
brâncovenesc de la Hurezi, în jurul căreia sunt aliniate 12 figuri de Sfinți Părinți ai Bisericii din tradiția greacă, latină şi siriacă. Dacă partea din față sugerează slava Trupului euharistic al catapetesmei, cea din spate străvede slava Sângelui, este o perdea de sânge, care-şi lasă pecețile pe veşmântarul din spatele fiecărei icoane împărăteşti şi de hram (Cămaşa lui Hristos; Veşmântul slavei; Haina veseliei; Mir revărsat). Din punct de vedere practic, iconostasul ține loc şi de veşmântar, ducând la regăsirea dimensiunii iconice şi eshatologice a înveşmântării sacerdotale.

Urzeala hermeneutică a diferitelor tipologii este asigurată printr-o textură prețioasă formată din miezuri şi peceți liturgice gravate pe trupul catapetesmei: Via Domnului; Ciorchinele milostivirii; Vița lui Iesei; Frângerea pâinii; Pâinea vieții; Paharul binecuvântării; Vinul tainic; Catapeteasma zilei a opta; Norul slavei; Nor de martori. De asemenea, înscrisurile din ciclul Deisis „Nu mai au vin" (Maica Domnului) şi "Iată, Mielul lui Dumnezeu, Cel ce ridică păcatul lumii” (Sf. Ioan Botezătorul), ca şi prezentarea Crucii altarului ca şi carte a vieții lui Iisus Hristos, Mielul junghiat de la întemeierea lumii (Apoc. 13,8), sunt embleme ale misticii nupțiale euharistice.

O parte din Părinţii Bisericii sunt chemaţi de-a dreptul să liturghisească, prin cuvintele pe care le poartă: Sf. diacon Efrem Sirul: „Vremea este ca Domnul să lucreze”; Sf. Marcu Eugenicu: „Trimite Duhul Tău Cel Sfânt peste Jertfa aceasta”; Sf. Grigore Dialogul: „Să luăm aminte Sfintele Sfinților”, iar alții sunt invitați să teologhisească euharistic: Sf. Nicolae Cabasila: „Mistagogia aceasta este ca o icoană a trupului unic al Domnului" (Explicarea dumnezeieştii Liturghii); Sf. Atanasie cel Mare: „Acest Trup şi Sânge se dă vouă ca hrană duhovnicească"; Sf. ; Sf. Gigore de Nyssa: „Sfântul Sfinților în Sfânta Sfintelor”; Chiril al Alexandriei: „Catapeteasma Trupului lui Hristos ascunde măreția Logosului”; Sf. Meliton de Sardes: „Ciorchinele este Biserica ori trupul tainic al Domnului”; Sf. Augustin: „Primul ciorchine zdrobit în teasc este Hristos"; Sf. Fotie al Constantinopolei: „Iisus Hristos, Mirele Bisericii lui Dumnezeu”; Sf. Isaac Sirul: „Duminica este taina 
cunoaşterii adevărului”; Sf. Grigorie Palama: „Pâinea aceasta este ca o catapeteasmă". Dacă arhitectul a gândit forma locaşului ca o vibrație, pulsație şi rezonanță a misterului liturgic în afară, preotul şi iconograful vin să adauge, prin imaginea centrală de pe spatele catapetesmei, că această pulsație este dată de Hristos, Inima Bisericii, care bate într-un ritm euharistic, sistolic şi diastolic.

Pe latura sudică a altarului, reprezentările au ca scene premergătoare Ospitalitatea lui Avraam, apoi Jertfele lui Abel şi Melchisedec, registrul secund desfăşurând deja seria marilor praznice ce se continuă în naos şi pronaos, marcându-se începutul acestora prin Buna Vestire şi Naşterea Mântuitorului, ca apoi partea de jos a altarului să includă ultimele scene: Cina din Emaus, Moise lovind piatra din care curge apa, simbol baptismal şi euharistic. Bunavestire cuprinde o subtilă abordare tematică legată de metafora țeserii trupului lui Emanuel din porfira împărătească a sângelui Preacuratei Fecioare Maria, strănepoată a regelui David. Încuviinţarea Fecioarei („Fie!”) reia titlul unei celebre predici a mitropolitului Bartolomeu Anania. De asemenea, scena Naşterii Domnului cuprinde o formulă concentrată în cadrul căreia sunt redate simbolic, în partea de jos, cele trei cupe cu darurile magilor şi cele trei „flori sfinte” din grădina raiului, grâul, vinul şi mirul, din colindele româneşti.

Cupola şi turla : simbolizând cerul cupola redă viziunea cerească a Pantocratorului, iar mai jos Liturghia îngerească, cu Iisus Mare Arhiereu slujind la altarul aflat sub un baldachin. Îngerii descriu întreaga dinamică liturgică pe care o regăsim în momentul Vohodului Mare, din cadrul Sfintei Liturghii. Tavanul este destinat reprezentării Ierarhiilor îngereşti, compunerea spaţiului fiind organizată într-un octogon, simbol al zilei a opta, în colțurile lui fiind figuraţi serafimi şi heruvimi, liturghisind în momentul special al Heruvicului. Întreaga compoziție este completată de texte-cheie din Slujba Sfintei Liturghii sau alte texte liturgice, mesaje ce se vor regăsi în întregul ansamblu parietal, pe lângă funcția slujitoare având şi o funcție decorativă. De tavan este legată şi simbolica candelabrului pascal al bisericii, cu formă octogonală, conformat 
integral simbolicii luminii eshatologice a zilei a opta, decorat cu opt heruvimi din alamă pe inelul octogonal, purtând opt candele de sticlă, iar pe partea interioară a inelului având gravat textul imnului Heruvimic: „Cari pre heruvimi tainic închipuim şi de viață făcătoarei Treimi întreit sfântă cântare aducem".

Naosul : Programul iconografic al naosului pivotează în jurul celor două mega-scene dispuse în absidele evazate, având o formă particulară: Pogorârea la Iad (la sud) şi Pogorârea Duhului Sfânt (la nord). Cele trei paliere de scene ce compun orizontal întreg corpul bisericii surprind prefigurări vechi-testamentare sau paremii la marile praznice, mai cu seamă cele din absidele laterale. Partea superioară a acestora cuprinde două reprezentări nonfigurative, scena Duhului ce se purta pe deasupra apelor, la sud, şi un clipeu cu Tronul Etimasiei, parte constitutivă a scenei Cincizecimii.

Flancul sudic: scena Facerii lui Adam, Duhul germinând apele primor-diale, Păcatul originar, Izgonirea din Eden. Scena centrală a Pogorârii la Iad este flancată de alte două mari praznice, Naşterea şi Botezul Domnului, desfăşurate pe o suprafață mai largă, iar dedesupt Noe în arcă şi Iona ieşind din pântecele chitului, scene cu dublă semnificație: neofitul care iese din apa bote-zului, iar pe de altă parte defunctul care iese din mormânt.

Flancul nordic: din primul registru, sus, ce recuperează pe întreg parcursul lui reprezentări ale proorocilor destinate în general turlei, s-a pictat Înăltarea la cer a Sf. Ilie şi Viziunea lui Iezechiel. Registrul median alătură praznicul Înăl-țării Domnului scenei Injumătățirii Praznicului. Registrul inferior include încă două scene ale aceluiaşi ciclu: Duminica samarinencei şi Izvorul Tămăduirii.

Pronaosul. Latura sudică: din viața lui Moise, ca prefigurare a praznicului Schimbării la față, Vechiul Testament ne înfățişează scena Coborârii de pe Sinai şi a Vălului de pe fața lui Moise. Episoadele se succed cu Minunea îndulcirii apei la Mera şi Trecerea chivotului Legii prin Iordan. Scenele vetero-testamentare din imediata vecinătate a întregului perete de apus, destinat vieții Maicii Domnului, sunt astfel organizate încât să reactualizeze momentelecheie din viața Fecioarei legate de Întrupare. În acest sens, ultimul 
registru din vecinătatea sfinților în picioare include scenele: Daniel în groapa cu lei, Cei trei tineri în cuptorul de foc al Babilonului, Trecerea Mării Roşii, Ghedeon şi roua pe lână, în acelaşi timp prefigurări ale momentului pascal şi baptismal, teme centrale ale Teofaniei şi Paştilor (Sâmbetei Mari).

Peretele de nord derulează, în aceeaşi ordine de idei, în registrul superior, scene dedicate prefigurărilor biblice şi profeților, precum: Rugul aprins, Şarpele de aramă în pustiu, Lupta lui Iacov cu Îngerul, Viziunea lui Isaia. Celelalte două registre sunt destinate reprezentării Ciclului Patimilor (cel median): Tânărul gol din grădina Ghetismani , Batjocorirea lui Hristos şi Răstignirea,. se continuă cu ilustrarea scenei Duminica Tomii, imagine care face sinapsa cu semnificațiile scenei Nunta din Cana, pictată dedesubt, iar în zona inferioară, cu scena Tăierii capului Sf. Ioan Botezătorul şi praznicul Inălțării Sfintei Cruci, în strânsă legatură cu scenele desfăşurate pe axul vertical, compunere care, la o lectură mai atentă, se regăseşte la nivelul întregii formulări iconografice.

Compunerea peretelui vestic s-a concentrat asupra patru scene majore: sus Naşterea şi Intrarea în Templu a Maicii Domnului, având în centru ilustrarea versetului din psalmul 44 (,Stătut-a împărăteasa de-a dreapta $\mathrm{Ta}$, îmbrăcată în haină aurită şi prea înfrumusețată"), scenă unică în iconografia românească, adaptată după celebrul model în mozaic al lui Jacopo Torriti (1295-1296) de la basilica Santa Maria Maggiore, autohtonizată discret, prin forma şi decorația tronului (rozeta solară şi semnul lunii). Deasupra intrării principale, scena Adormirii Maicii Dommului are o desfăşurare amplă, dispusă pe înălţimea a două registre obişnuite, beneficiind de o abordare teologică pe măsură, care accentuează atât dimensiunea de Paşte al Bisericii, cât şi legătura acestui praznic cu Corpus-ul Areopagitic $^{44}$, adică cu tradiția siro-palestiniană (Sfinții Dionisie şi

\footnotetext{
${ }^{44}$ Jan Nicolae, Pathei mathos: învătarea prin pătimire a celor dumnezeieşti sau Sfinții Dionisie şi Ierotei în contextul hagiografic, omiletic, imnografic şi icono-logic al sărbătorii Adormirii Maicii Domnului, în Picu Ocoleanu (coord.), Teologie şi filosofie în opera Sfântului Dionisie Areopagitul, partea a
} 
Ierotei sunt înfăţişaţi ca „apostoli ai Maicii Domnului”, alături de imnografii Ioan Damaschinul şi Cosma de Maiuma). Deasupra uşii de intrare şi dedesubtul mega-scenei Adormirii Precestii este reprezentată conjuncția liturgică între zilele de 15 şi 16 august, prin mandylionul martiric brâncovenesc (redarea iconografică a îngemănării fețelor martirilor cu Fața lui Hristos, Martirul martirilor).

Şirul sfinților mucenici şi mucenițe, cuvioşi şi sfinți români va ține seama de caracterul arhitecturii de tip bazilică/ navă, precum şi de specificul zonal, al sfinților transilvăneni, cu trimiteri la tipul de abordare iconografic, euharistic şi catehetic, într-o alăturare şi relaţie permanentă de-a lungul celor doi versanți, drept şi stâng. Dincolo de Tradiție şi afinităţile personale, am avut în vedere, în acelaşi timp, în alegerea sfinților, dimensiunea antropologică exprimată într-o teologie a tuturor vârstelor şi stărilor (ierarhi, preoți, mireni) care participă la pleroma Bisericii, într-o diversitate de vocații şi harisme. Şi în acest orizont antropologic şi cultural, biserica se prezintă ca o arcă universală, ca un chivot ecumenic.

Pe flancul sudic, pornind dinspre catapeteasmă, şirul ni-l înfățişează pe Dreptul loachim, părintele trupesc al Maicii Domnului, acesta având-o pe peretele din față, în oglindire, reprezentată pe Sf. Ana cu prunca Maria în brațe. Urmează cadrul alocat sfinților mucenici, mărturisitori, ostaşi: Sf. Mare Mucenic Gheorghe şi Sf. Eustatie Plachida, în dreptul absidei sudice, pentru ca în cea opusă, nordică, să-i regăsim pe Sf. Mare Mucenic Dimitrie şi Sf. Mare Mucenic Mina. Sf. Mucenic Doctor anarghir Pantelimon, tânărul mirean thaumaturg, face punte cu prezența iconică a $S f$. Ioan de Kronstadt, cu potirul în mână, urmat îndeaproape de ucenicul Cuviosului Siluan, Sf. Sofronie Saharov, trăitor în Muntele Athos şi ctitor al mănăstirii Sf. Ioan Botezătorul de la Essex (Anglia), în curs de canonizare în toamna anului 2014. Pe flancul nordic, dintre sfinții români, Sf. Mucenic Ioan Valahul (sec. XVII), tânărul care a biruit

II-a, Studia Theologica 3, Craiova, Editura Mitropoliei Olteniei, 2012, pp. 215264. 
lupta cu ispita păcatului trupesc urmat de Sf. Nicolae Oprea (sec. XVIII), mucenicul şi mărturisitorul țăran şi Sf. Mărturisitor Atanasie Todoran, sunt exponenții prin excelență ai luptei pentru credința ortodoxă în Transilvania. Preoțimea de mir şi familia preoțească mărturisesc prin presbiterul Montanus, sfânt mărturisitor daco-roman în ținuturile de la Dunăre, la anul 304, în vremea lui Dioclețian, alături de preoteasa Maxima, înfățişată în dreapta lui, aceştia fiind prima pereche sacerdotală, de preot şi preoteasă, cunoscuți cu numele din cadrul romanității orientale. Totodată, profeția pe care acest martir o face despre ridicarea unui popor credincios reprezintă un reper al nobleții romanităţii încreştinate. Mesajul profetic şi martiric face pandant cu sinteza euharistică de la proscomidiar în sensul unei dinamici euharistice şi a unei revărsări a bogăției duhovnioceşti a neamurilor în pleroma ecumenică a Bisericii.

La sud, după grupul sfinților militari si preoti, ceata cuvioşilor îi cuprinde în sinaxă pe Sf. Sofronie Ardeleanul (sec. XVIII), Sf. Antonie cel Mare (+356), Sf. Sava cel Sfintit din pustia Palestinei (+450), Sf. Ioan Scărarul (+649), Sf. Maxim Mărturistorul (+662), Sf. Simeon Noul Teolog $(+1022)$. Sf. Nicodim Aghioritul $(+1809) .0$ iconografie inedită o avem deja pe peretele vestic, din spate, prin înfățişarea Sf. Mucenic Hristofor, cu cap de miel, reprezentare ce merita o recuperare din tradiția bisericilor de sat, mai ales că de curând i-a fost dedicată o remarcabilă cercetare ${ }^{45}$. Latura sudică a peretelui de vest se încheie cu grupul Sfinţilor Mucenici Macabei cu mama lor Solomonia, care închid şirul ultimei perioade a Vechiului Testament şi deschid procesiunea mucenicilor Bisericii. Lângă uşa de intrare, Sf. Cuvios Zosima cel care ne descoperă viața Sf. Maria Egipteanca, reprezentată imediat lângă accesul principal în biserică, primind Sfânta Împărtăşanie, îndemn spre cuminecare fiecărui credincios participant activ la viața liturgică întru dobândirea Chipului celui adevarat al lui Hristos. Un mare mărturisitor şi Părinte apostolic al Bisericii este Sf. Mucenic şi Ierarh Ignatie Teoforul

\footnotetext{
${ }^{45}$ Silvia Marin-Barutcieff, Hristofor: chipurile unui sfânt fără chip, Editura Mega, Cluj-Napoca, 2014.
} 
$(+107)$, chipul euharistic al episcopului prin excelență, martirizat la Roma, în arenă, sfâşiat de leii înfometaţi, dezvoltând anticipat o adevărată teologie euharistică a martiriului ${ }^{46}$, care se cuvenea integrată în ampla desfăşurare euharistică din această biserică: „Eu sunt grâul lui Dumnezeu şi doresc să fiu măcinat de dinții fiarelor ca să fiu găsit pâine curată a lui Hristos”47. În fapt, întreg acest registru hagiografic din preajma uşii doxologice de intrare redă vizual conceptul de matrice euharistică a Bisericii.

Revenind pe zona nordică, şirul sfintelor femei se deschide cu Sf. Maxima - presbitera, Sf. Mare Muceniţă Ecaterina, chip al înțelepciunii şi frumuseții, Sf. Cuvioasă Teodora de la Sihla, Sf. Cuvioasă Parascheva de la Iaşi şi Sf. Muceniță Filofteia de la Curtea de Argeş, continuând la vest cu Sfintele Mucenițe Sofia şi cele trei fiice, Elpis, Pistis şi Agapis. Alegoric, este întruchipat gândul întemeierii şi consistenței euharistice a virtuților.

Deşi iniţial biserica a fost concepută să fie împodobită cu frescă sau mozaic şi în exterior, până la urmă forma sa sculpturală deosebită, greu de citit sub o cuvertură de frescă, a făcut ca totul să fie regândit, ajungându-se la formula finală a unei mega-icoane a Arhe-Chipului (Mandylion) la intrare, pe fațada curbată de deasupra uşii, sub forma unei vele de corabie sau a unui prapor (à la Horia Bernea), surmontată de un grafitti cu rugăciunea de intrare „Binecuvantată este intrarea sfinţilor Tăi totdeauna, acum şi pururea şi în vecii vecilor. Aliluia". Acest crol cuprinde de jur-împrejur întreg locaşul, integrând, după modelul Mandilyon -ului de la intrare, câte o figură decorativă, un heruvim în dreptul fiecărei abside laterale şi Mielul biruitor, în dreptul absidei altarului. Textele alese să decoreze friza din exterior sunt fragmente semnificative din slujba sfințirii bisericii, menite să ilustreze sensul acesteia de casă a slavei Domnului Treimic şi de străfulgerare a frumuseții Logos-ului. Locaşul este o cutie de rezonanţă a misterului liturgic, o cutie

${ }^{46}+$ Irineu Slătineanul, Martiriul ca jertfă euharistică, în Picu Ocoleanu, Radu Preda (ed.), Viață liturgică şi etos comunitar. Preliminarii la o teologie socială ortodoxă, Craiova, Editura Mitropolia Olteniei, 2007, pp. 15-31.

${ }^{47}$ Sf. Ignatie, Epistola către Romani, IV, apud Irineu Slătineanul, op.cit., p. 19. 
perspectivă eshatologică dar şi o „,cutie neagră” de texte esenţiale în sensul cuprinderii propriei memorii liturgice.

Ambientul liturgic sonor va fi îmbogățit în exterior de carillonul (Glockenspiel) montat în clopotnița specială, proiectată de arhitectul Dorin Ştefan după modelul unei zvonițe medievale, cu clopotele la vedere. Numărul de aur al bisericii, 12, se păstrează inclusiv în muzica celor 12 clopote mici, acompaniate de cel mare, central, fabricate la turnătoria celebrei abații benedictine Maria Laach (Ars liturgica), personalizate după numele sfinților ocrotitori: clopotul central - Sf. Ioan Teologul, vulturul Logos-ului, cele şase clopote dinspre intrarea în curtea bisericii - Sfinţii Mucenici Brâncoveni, iar celelalte şase - Sf. Ioan Botezatorul, Sf. Ioan Hrisostomul, Sf. Nicolae, Sf. Simion Ştefan, Sf. Varlaam, Sf. Antim Ivireanul. Pe clopotul mare, alături de inscripția votivă şi blazon, se va afla imaginea teascului mistic al muceniciei, ca imagine emblematică pentru această biserică. Muzica clopotelor se leagă de funcţia locaşului de rezonator al misterului liturgic ilustrată într-o serie de semne iconografice şi într-o tainică osmoză muzicală între interior şi exterior: altarul din scena Împărtăşirii Apostolilor, tronurile şi piedestalurile mariane muzicale, baldachinul Adormirii Precistii, unduirea şi ritmul muzical al apelor şi al teofaniilor, aripile îngerilor în formă de liră de lumină, partitura muzicală octogonală a Heruvikon-ului şi Trisaghionului, Aliluia de deasupra intrării, muzica peceților cărții pe care stă Mielul biruitor, şi, nu în ultimul rând, rezonanța muzicală sugerată de banda grafitti exterioară din slujba sfințirii, care uneşte Liturghia euharistică cu Liturghia cosmică. Această funcție muzicală a rezonanței cosmice a fost dimensiunea centrală sub care a fost prezentată această biserică în Courier international, portalul revistei Le Monde, în martie 2014.

Fructificând cercetările dedicate morfologiilor plastice ale Crucii în patrimoniul românesc ${ }^{48}$, decorul podoabă de la uşa de intrare se va conexa cu tematica eshatologică a Feței Domnului: pe

48 Jan Nicolae, Ana Dumitran, Ioana Rustoiu, Slavă-Viață. Crucea in patrimoniul spiritual al județului Alba, Editura Altip, Alba Iulia, 2010. 
cele două canaturi unite de o formă de cruce cu înscrisul paleocreştin $Z \Omega N-\Phi \Omega \Sigma$ (viață-lumină, viaţă-slavă) vor fi reprezentați în bronz doi îngeri purtând pe frunte soarele şi luna, iar decorul va cuprinde înscrisuri biblice şi liturgice: „Cer nou; Pământ nou; Aliluia, Aliluia, Aliluia”; nucleul central al doxologiei mari: „Slavă întru cei de sus lui Dumnezeu şi pe pământ pace, între oameni bunăvoire. Lăudămu-Te, bine Te cuvântăm, închinămu-ne Ție, slăvimu-Te, mulțumim Ţie pentru slava Ta cea mare. Doamne, Impărate ceresc, Dumnezeule, Părinte atotţiitorule, Doamne, Fiule, Unule-Născut, Iisuse Hristoase şi Duhule Sfinte. Doamne Dumnezeule, Mieluşelul lui Dumnezeu, Fiul Tatălui, Cel ce ridici păcatul lumii, miluieşte ne pe noi, Cel ce ridici păcatele lumii. Primeşte rugăciunea noastră, Cel ce şezi de-a dreapta Tatălui, şi ne miluieşte pe

noi.

Că Tu eşti Unul Sfânt, Tu eşti Unul Domn Iisus Hristos, întru slava lui Dumnezeu Tatăl. Amin.”.

Decorul uşii de intrare cuprinde pe partea din interior doi îngeri cu buciumele Apocalipsei pe cele două canaturi, pecetluite cu înscrisurile „Alfa şi omega" şi „Împăratul împăraților şi Domnul domnilor. Amin. Aliluia" din cartea Apocalipsei, accentuând intrarea comunităţii Bisericii ca nou Israel în spaţiul împărătesc al dumnezeiscului ospăț. Uşa laterală din coasta altarului, lovită şi ea de îngerul artei liturgice, va avea aceeaşi stilistică, fiind legată de tema călcării lui Hristos în teasc (Isaia 63, 3) şi a lui Hristos ca Ciorchine mistic. Pe partea interioară, teascul Pătimirii, după un model miniatural, maestrul din Engelberg, dintr-un manuscris cuprinzând comentariul Sf. Augustin la Psalmi, din anul 1175 (Engelberg Stiftsbibliothek, cod. 12, 155ff). Înscrisurile dau o prețiozitate teologică specială. Pe exterior: Ceruri deschise; Aliluia; Pământul făgăduinței; Împărăția. La interior: „Teascul Domnului; Aliulia, Aliluia, Aliluia; Vin tainic; Maranatha; Amin, Amin, Amin" De împodobirea uşilor şi de candelabrul bisericii s-a ocupat artistul plastic Virgil Scripcariu, în colaborare cu pictorul Ioan Popa, cu arhitectul Dorin Ştefan şi cu preotul paroh. 
De asemenea, mobilierul (strane, tronuri, bănci), specific unei basilici, a fost conceput de arhitectul George Macovescu, după consultări cu toți cei implicați în estetica ambientală a acestui spațiu liturgic, şi executat de firma Schosswender Mobel din Căpâlna, a celebrului handbalist Simon Schobel.

\section{Concluzii}

Aşadar, arca noetica de la Alba Iulia, cea mai nou biserică din cetatea de lumină şi mucenicie a românilor, oferă o desfăşurare a unui amplu şi dens program iconografic (rotulus-ul Împărăției), întro inedită coregrafie arhitecturală şi iconografică, înfățişând faptul esențial al locuirii liturgice a „întregului Adam” cu Dumnezeul său, din raiul cel vechi până în Templu, de la iad până în eshaton. Deşi i-a asumat spiritual pe Sfinții Brâncoveni ca hram de temelie, nu adoptă mimetic stilul brâncovenesc, ci dezvoltă o viziune plastică de profundă sinteză simbolică în zona universală a arhetipurilor, într-un orizont teologic vast, de factură ioaneică, care îngemănează cultura Logos-ului şi a Duhului, adică înnobilarea prin credință şi cultură, locuirea liturgică a lui Dumnezeu cu oamenii sub aripile Paracletului, în revărsarea luminii zilei celei neînserate.

\section{Bibliografie:}

1. †Daniel, Patriarhul Bisericii Ortodoxe Române, Brâncuşi. Sculptor creştin ortodox, Iaşi, Editura Trinitas, 2007.

2. Dumitrescu, Sorin, Chivotele lui Petru Rareşş şi modelul lor ceresc, Bucureşti, Editura Anastasia, 2003.

3. Idem, Chivotul mediatic de la Alba Iulia. Analiză de caz - studiu iconologic - prezentare iconografică, în „Igloo”, 124 (2012).

4. Ioan, Augustin (coord.), Concursuri pentru catedrala patriarhală ortodoxă: 1999-2002, București, Editura Noi Media Print, s. a.

5. Idem, Arhiepiscopul Chrysostomos. Arhitectura în Biblie şi la Sfintii Părinți, Bucureşti, Pro Universitaria, 2013.

6. Idem, Visul lui Ezechiel. Corp, geometrie şi spațiu sacru, București, Editura Anastasia, 1996. 
7. Marin-Barutcieff, Silvia, Hristofor: chipurile unui sfânt fără chip, Cluj-Napoca, Editura Mega, 2014.

8. Marion, Jean-Luc, Despre raționalitatea Revelației şi irationalitatea credincioşilor, trad. rom. Maria Cornelia Ică jr., Sibiu, Editura Deisis, 2015.

9. Moldovan, Ilie, În Hristos şi în Biserică: iubirea euharistică generatoare de viață şi destin românesc, Alba Iulia, Editura Reîntregirea, 2011.

10. Moldovan, Ilie, Ioan Nicolae, Calendarul viu. Dialoguri euharistice intre generații, Alba Iulia, Editura Reîntregirea, 2007.

11. Nicolae, Jan (coord.), Mitropolitul Simion Ştefan. Sfântul cărturar al Transilva-niei, Alba Iulia, Editura Reîntregirea, 2012.

12. Idem, „Potirul este viața mea”. Părintele Ioan Cuminecătorul. Euharistie şi martiriu în viața unui preot român in inchisorile comuniste, în Mihai Himcinschi, Jan Nicolae (coord.), Eucharist and Martyrdom from ancient catacombs to the communist prisons, ISSTA 2014, vol. I, Alba Iulia, Editura Reîntregirea, 2014.

13. Nicolae, Jan, Ana Dumitran, Ioana Rustoiu, Slavă-Viață. Crucea in patrimoniul spiritual al județlui Alba, Alba Iulia, Editura Altip, 2010.

14. Nicolae, Jan, Arca noetica de la Alba Iulia, în „Arhitectura”, nr. 6, 2013.

15. Idem, Architecture. Une forme qui cloche, în „Courrier international2, 13 mars 2014 (www.arhitectura-1906.ro).

16. Idem, Iconografia Euharistiei: Hristos, vița cea adevărată şi vimul adevă-rului, Alba Iulia, Editura Altip, 2014.

17. Idem, Omiletica brâncovenească şi medicina. De la "mreaja bogosloviei" la "meşterşugul doftoresc". Elemente de theologia medicinalis în opera Sfântului Antim Ivireanul, în „Tabor”, an VII, nr. 10, octombrie 2013, Cluj-Napoca, 2013.

18. Idem, Pathei mathos: învătarea prin pătimire a celor dumnezeieşti sau Sfinții Dionisie și Ierotei în contextul hagiografic, omiletic, imnografic şi icono-logic al sărbătorii Adormirii Maicii Domnului, în Picu Ocoleanu (coord.), Teologie şi filosofie în opera Sfântului Dionisie Areopagitul, partea a II-a, Studia Theologica 3, Craiova, Editura Mitropoliei Olteniei, 2012.

19. Pauly, Daniele, Le Corbusier: La Chapelle de Ronchamp, Basel, Birkhauser, 1997.

20. Rotaru, Irina, Biserica din Cartierul Nou - Alba Iulia, în „Arhitectura", nr. 59, noiembrie 2007.

21. Ștefan, Dorin, Carte de bucate de arhitectură, grafica: Corina Gabriela 
Duma, red: Viorica Buică, Igloo, București, 2009.

22. Stoller, Ezra, The Chapel at Ronchamp, New York, Princeton Architectural Press, 1999.

23. Tabart, Marielle, Brâncuşi. Inventatorul sculpturii moderne, trad. rom. Emilia Munteanu, București, Editura Univers, 1995.

24. Wilson, Adrian, Joyce Lancaster Wilson, Medieval Mirror. Speculum Humanae Salvationis 1324-1500, University of California Press, Berkeley - Los Angeles - Oxford, 1985.

25. Zeck, Ariadna, Occidentalizarea si/sau laicizarea arhitecturii religioase din Tara Românească. 1780-1885, teză de doctorat, Bucureşti, 2000.

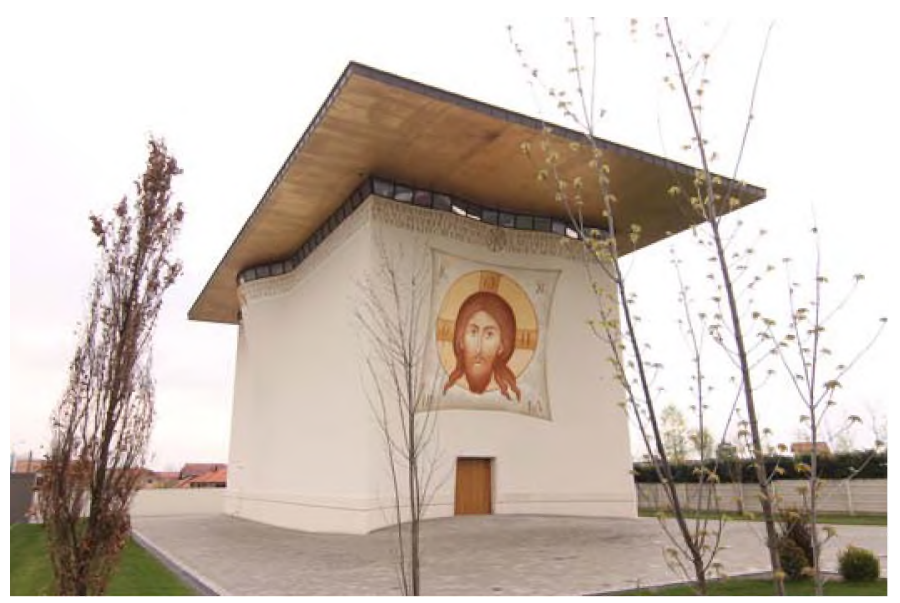

Figure 1: Fatada bisericii 
$14^{\text {th }}$ International Symposium on Science, Theology and Arts

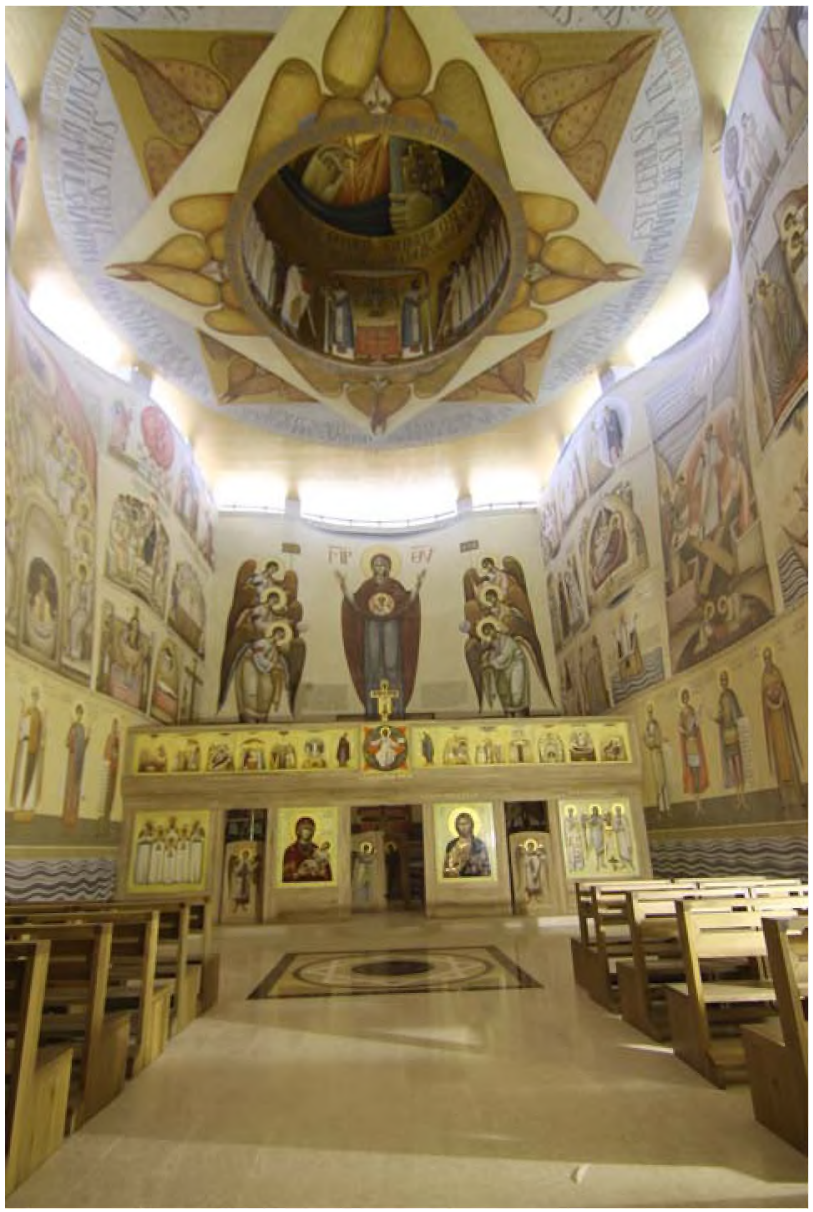

Figure 2: Vedere de ansamblu din interior 
$14^{\text {th }}$ International Symposium on Science, Theology and Arts

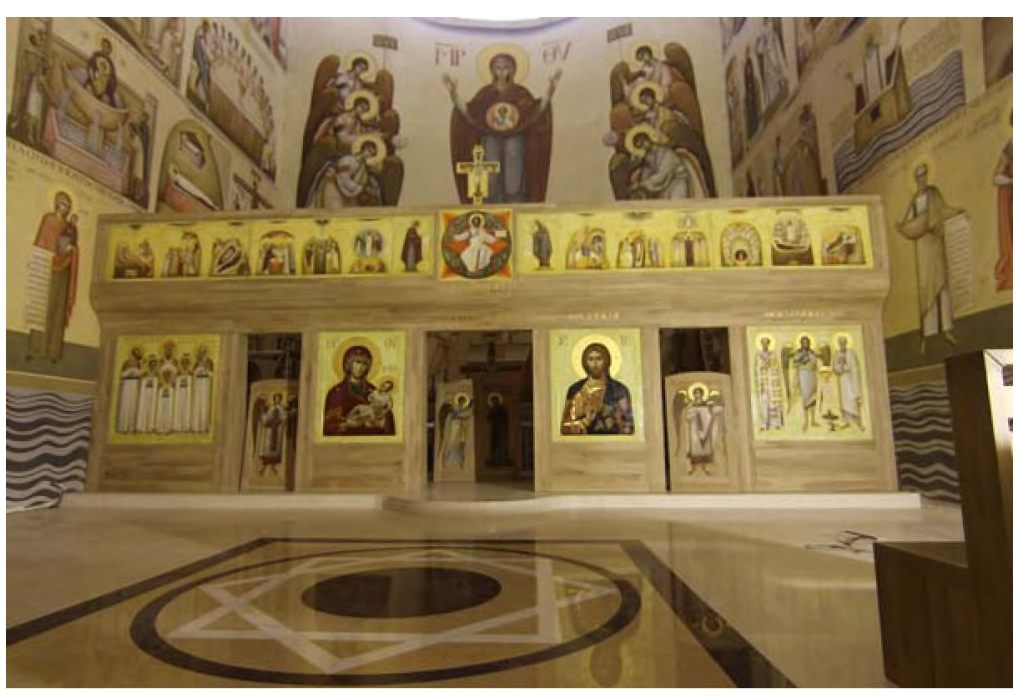

Figure 3: Catapeteasma bisericii 